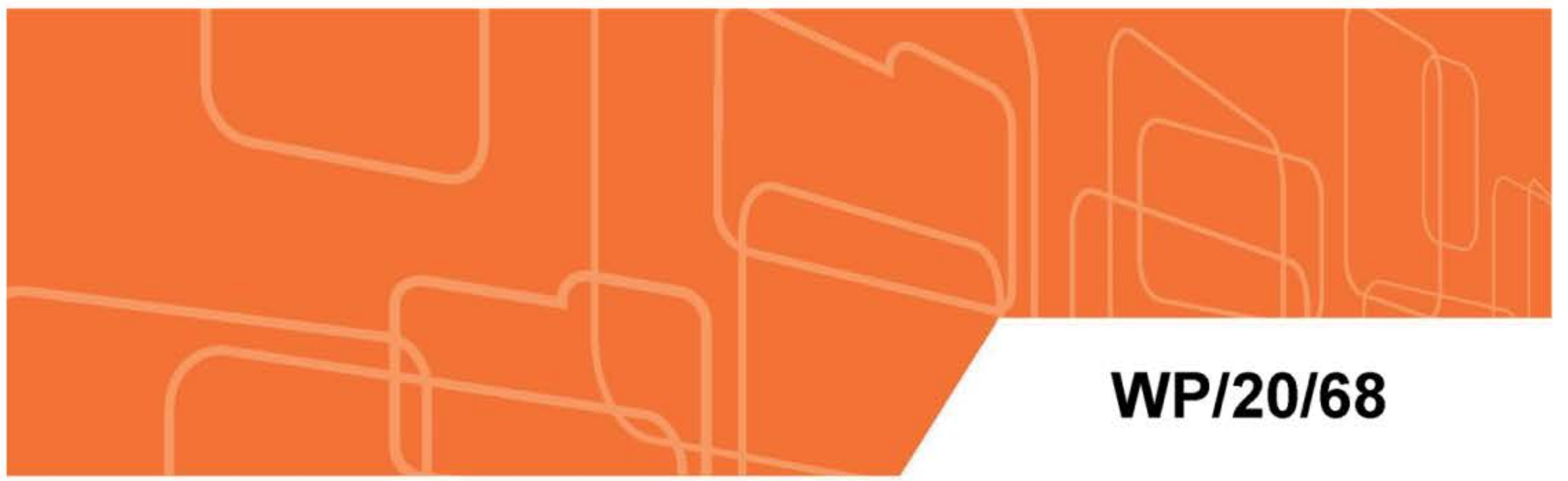

IMF Working Paper

\title{
Can Digitalization Help Deter Corruption in Africa?
}

by Rasmane Ouedraogo and Amadou N.R. Sy

IMF Working Papers describe research in progress by the author(s) and are published to elicit comments and to encourage debate. The views expressed in IMF Working Papers are those of the author(s) and do not necessarily represent the views of the IMF, its Executive Board, or IMF management. 


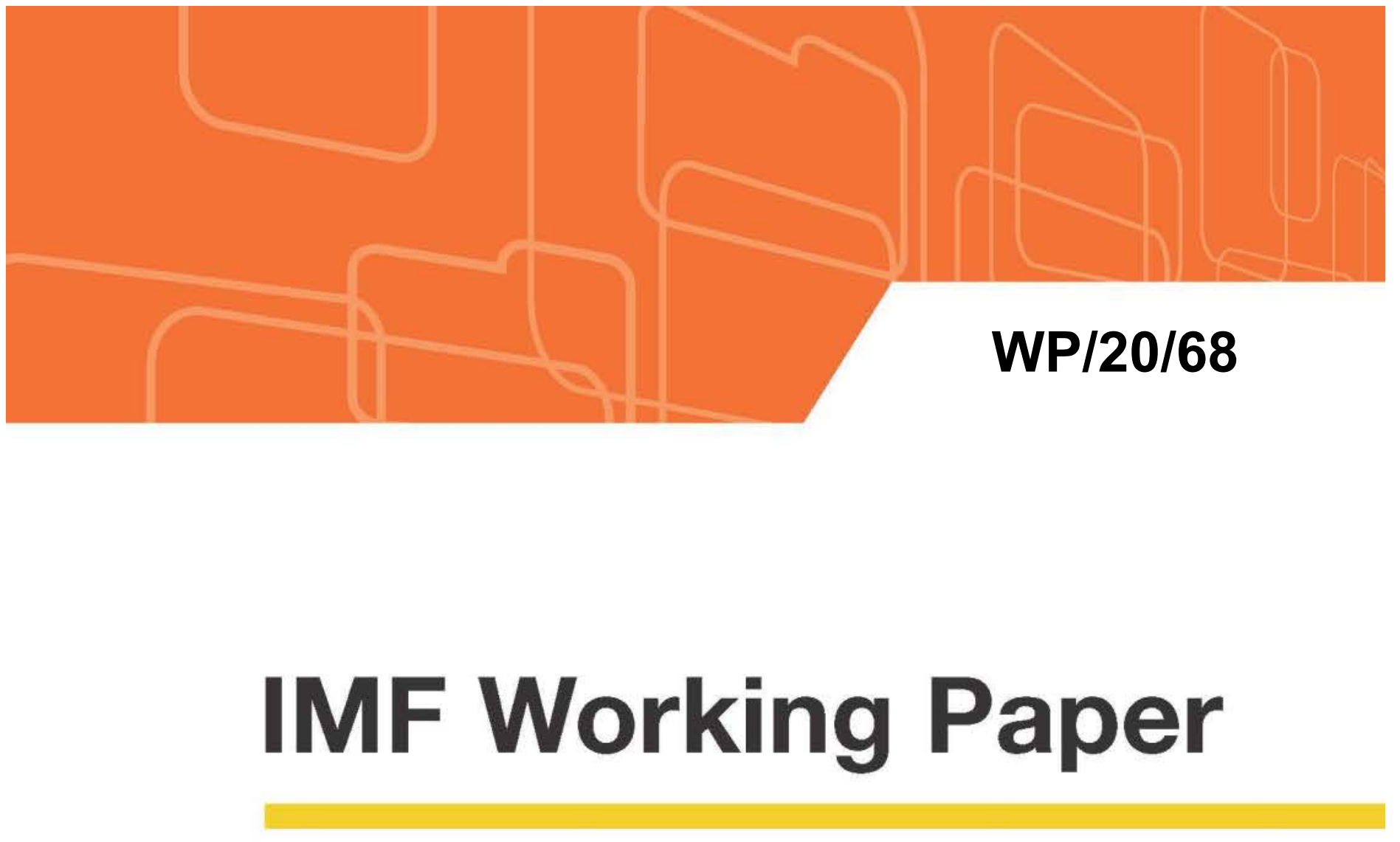

\section{Can Digitalization Help Deter Corruption in Africa?}

by Rasmane Ouedraogo and Amadou N.R. Sy

IMF Working Papers describe research in progress by the author(s) and are published to elicit comments and to encourage debate. The views expressed in IMF Working Papers are those of the author(s) and do not necessarily represent the views of the IMF, its Executive Board, or IMF management.

$$
\text { I N T ER N A T I O N A L MONETAR Y FUND }
$$




\title{
IMF Working Paper
}

African Department

\section{Can Digitalization Help Deter Corruption in Africa?}

\author{
Prepared by Rasmane Ouedraogo and Amadou N.R. Sy
}

May 2020

IMF Working Papers describe research in progress by the author(s) and are published to elicit comments and to encourage debate. The views expressed in IMF Working Papers are those of the author(s) and do not necessarily represent the views of the IMF, its Executive Board, or IMF management.

\begin{abstract}
This paper studies the effect of digitalization on the perception of corruption and trust in tax officials in Africa. Using individual-level data from Afrobarometer surveys and several indices of digitalization, we find that an increase in digital adoption is associated with a reduction in the perception of corruption and an increase in trust in tax officials. Exploiting the exogeneous deployment of submarine cables at the local level, the paper provides evidence of a negative impact of the use of Internet on the perception of corruption. Yet, the paper shows that the dampening effect of digitalization on corruption is hindered in countries where the government has a pattern of intentionally shutting down the Internet, while countries that successfully promote information and communication technology (ICT) enjoy a more amplified effect.
\end{abstract}

JEL Classification Numbers: D73, H20, L86, O33

Keywords: Digitalization, corruption, trust, Africa

Author's E-Mail Address: rouedraogo@,imf.org; asy@,imf.org 


\section{Table of Contents}

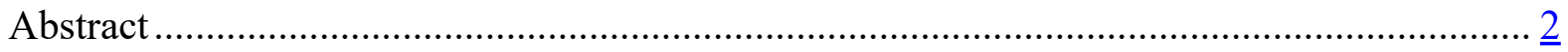

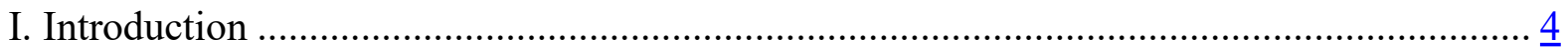

II. DATA SOURCES, EMPIRICAL METHODOLOGY AND STYLIZED FACTS ………... $\underline{8}$

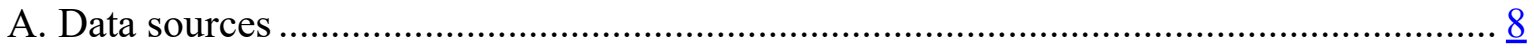

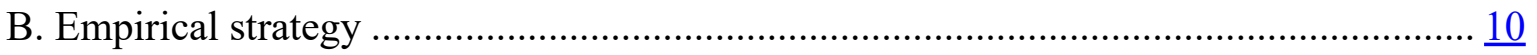

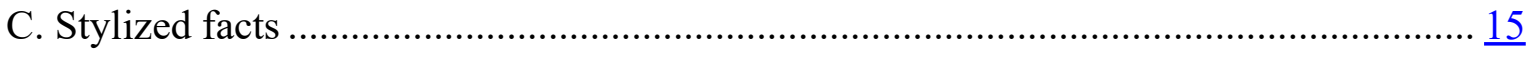

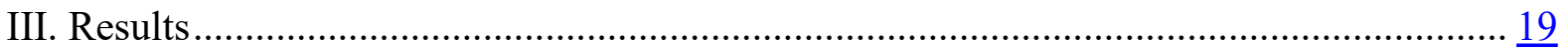

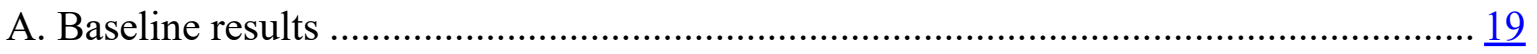

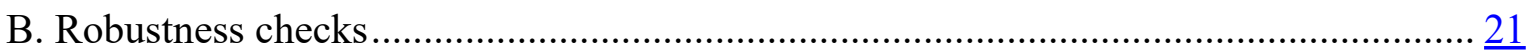

IV. Digitalization and trust in tax officials .................................................................... 24

V. Internet shutdowns and government success in ICT promotion ...................................... $\underline{26}$

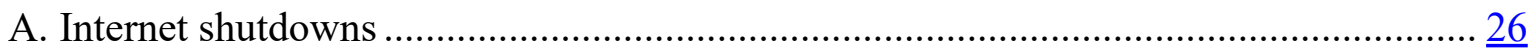

B. Government success in promoting ICT ………………..................................... 27

VI. The arrival of fast internet: identifying the causal effect of digitalization on corruption. $\underline{28}$

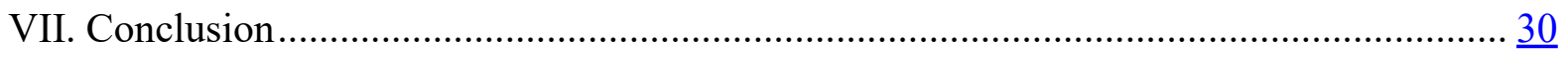

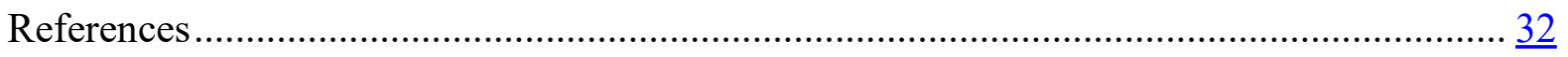




\section{INTRODUCTION}

African policymakers have committed to meet the Sustainable Development Goals (SDGs) by 2030. At the same time, they have recognized that corruption, is a key obstacle to mobilizing much-needed domestic revenues to meet the SDGs (African Union Commission, 2019). Several economic studies have also underscored the negative effects of corruption on fiscal revenues (Hammadi et al. 2019; d'Agostino et al., 2016; Fisman and Svensson, 2007; Hung, 2001). Recently, IMF (2019a) found that government revenues are significantly lower in countries perceived to be more corrupt. For example, among emerging and low-income countries, a country in the top 25 percent in terms of control of corruption collects $23 / 4$ and 4 percent of GDP more in revenues, respectively, on average, than a country in the lowest 25 percent. Realizing the potential gains of reduced corruption is essential for African economies in view of the estimated additional annual spending needs of \$2.6 trillion in low-income (and emerging markets) to reach the SDGs by 2030 (IMF, 2019b).

In this regards, African countries are increasingly considering digitalization as an important tool for the prevention, detection and prosecution of corruption (IMF 2018). In recent years, many sub-Saharan African countries have adopted new digital tools in tax administrations to reduce bureaucracy and combat corruption of tax officials. Digitalization is increasingly transforming how tax administrations operate, helping to improve process efficiency and service delivery and reduce the scope for corruption (Gupta et al., 2017). For countries that start with a high level of corruption, digitalization is associated with better control of corruption as it reduces human interactions (IMF 2019a). For instance, adopting digital tools in such countries could increase indirect tax collection at the border by up to 2 percent of GDP per year (IMF 2018).

In principle, digitalization can help promote transparency, accountability and citizen participation and facilitate advocacy and closer interaction of government and citizens (IMF, 2019a, IMF, 2018). In an environment of imperfect information, high transaction costs, and discretionary rent-seeking tasks, digitalization can help reduce search costs, disseminate information in a cost-effective way and reduce the moral hazard problem from monitoring public sector agents. Digital technology can also improve or provide educational services for public servants and the broader population at a lower cost. 
At the same time, digitalization can also create new opportunities for corruption. These opportunities are mostly related to cybercrime or simply through the misuse of well-intended technologies such as digital public services. Digital records and public service systems can be manipulated by corrupt officials with high IT skills. Digital systems are also vulnerable to cyberattacks, which can disrupt government functions and jeopardize citizens' digitally stored private information, particularly in countries with limited administrative capacity and underfunded security systems (IMF 2018; World Bank 2016). This implies that the impact of digitalization on corruption is unclear.

However, there is a paucity of empirical studies on the potential effect of digitalization on the perception of corruption. This paper fills this gap in the literature by estimating the effect of digitalization on the perception of corruption of tax officials in Africa. It does this by using individual-level data from the sixth wave of the Afrobarometer survey and various indicators of digitalization.

Afrobarometer represents a strong, reliable source of public opinion data within African states and contains some data on the citizens' perception of corruption of tax officials. Our sample covers more than 23,000 individuals from 26 African countries. To capture the level of digitalization, we use several indices that have been widely used in previous studies, including the World Bank's Digital Adoption Index and its components, the UN's e-Government, eParticipation and Online services indices and the World Bank's open budget et Public Financial Management (PFM) e-services indices. This allows us to rigorously explore the effect of digitalization on corruption. In addition, we exploit the exogeneous variations in the deployment of submarine cables at the subnational level to identify the causal effect of the use of internet on the perception of corruption.

Moreover, we explore a channel through which digitalization affects the perception of corruption in Africa. We argue that the potential dampening effect of digitalization on the perception of corruption could be related to its effect on trust in tax officials. In fact, by bringing transparency and reducing the opportunities for bribes and influence, digitalization can improve trust in government officials, which is a key element in the citizens' perceived level of corruption. Government values revolves around norms of integrity in terms of low 
perception of corruption and high standards of accountability, openness of the policy process to the participation of citizens (OECD 2018). The use of digital tools by governments-such as e-participation encourages greater collaboration with citizens by involving them in decision making, policy setting, problem solving, and the co-design of services. This could improve service quality, promote transparent and efficient interaction, and would contribute to enhance the level of public trust in government.

We also estimate non-linearity effects by exploring whether the intentional shutdowns of Internet and the government success in promoting ICT matter. The partial or total intentional outage of Internet prevents the free access to online information, the rights of citizens to get accurate information and undertake fact-checking and of businesses to operate transactions. West (2016) documented some 81 shutdowns between July 2015 and June 2016 and estimated the total cost of shutdowns to be in excess of $\$ 2.4$ billion over that period. Deloitte (2016) estimated that an average high-connectivity country stands to lose at least 1.9 percent of its daily GDP for each day all Internet services are shut down. For an average medium-level connectivity country, the loss is estimated at 1 percent of daily GDP, and for an average lowconnectivity country such as many African countries, the loss is estimated at 0.4 percent of daily GDP. Beyond this direct economic loss, Internet blackouts could undermine the trust of citizens in the Internet and government actions and raise the perception that the government is corrupt and has something to hide. Regarding the promotion of ICT, government policies are very important, not only in terms of ICT regulations but also for the education and availability of ICT related tools.

Our results are threefold. First, we find that a higher level of digital adoption is negatively associated with lower perception of corruption of tax officials. The paper shows that, on average, the adoption of digital tools is correlated with a reduction of corruption perception in the tax administration by around 4 percentage points. Second, the paper finds that the trust in tax officials is significantly higher in countries with higher level of digital adoption. Third, we find that the alleviating effect of digitalization on corruption perception is reduced when the government intentionally shutdowns the Internet, while a successful promotion of ICT by the government amplifies the dampening effect of digitalization on corruption. These findings are strongly consistent to the change in econometric model and regardless of the indicator used to 
capture the level of digitalization. Exploiting the exogeneous deployment of submarine cables at the subnational level (second administrative unit which can be the district, province or county depending on each country administrative division), we can identify the causal effect of the use of internet on the perception of corruption of tax officials. The paper implies that African countries should step digitalization, while managing the risks and challenges, to combat corruption on the continent. They should avoid intentionally internet shutdowns and rather establish policies to promote ICT development.

This paper contributes to the literature in several ways. First, it extends the growing body of studies on the effect of digitalization (Bellon et al., 2019; Kinda, 2019; Fan et al., 2018; Teltscher, 2002). However, this paper, to the best of our knowledge, is the first to focus on its effect on the perception of corruption and trust in tax officials. Given the perceived high level of corruption in Africa, this paper underscores that the adoption of digital tools would be crucial in the fight against corruption. Second, the paper provides a comprehensive empirical study about the effect of digitalization on the perception of corruption using various indicators of digitalization from several sources. This allows us to consider the different dimensions of digitalization, contrary to previous studies that look at only one component of digitalization or one digital tool (Bellon et al., 2019; Yilmaz and Coolidge, 2013). Finally, we contribute to the literature on the potential negative effect of internet shutdowns by showing how they alter the effect of digitalization on the perception of corruption.

The rest of the paper is organized as follows. Section 2 describes the data sources, the empirical methodology and provides some stylized facts. Section 3 presents the results from the empirical analysis, while Section 4 undertakes an extensive battery of robustness texts. Section 5 focusses on the non-linearity effects by exploring whether the effect of digitalization on corruption depends on the outcome of the government promotion of ICT and the intentional outages of Internet. Finally, Section 6 provides some concluding remarks. 


\section{DATA SOURCES, EMPIRICAL METHODOLOGY AND STYLIZED FACTS}

\section{A. Data sources}

Our primary source of data is the sixth round of Afrobarometer surveys which covers 36 African countries. The surveys were conducted in 2014/2015. As an independent, nonpartisan research project that measures the social, political, and economic conditions in Africa, Afrobarometer represents a strong, reliable source of public opinion data within African states. There is an increasing use of Afrobarometer data in the literature (Isaksson and Kotsadam 2018; Konte, 2016; Khemani 2015; Ali, Fjeldstad and Sjursen 2014; Justesen and Bjornskov 2014), which reflects a certain confidence on the reliability and quality of the data. Nationally representative samples of individuals who are more than 18 years old are selected both in rural and urban areas of the different countries. Multilevel random selection methods are used to generate the samples, which are representative cross-sections of the population.

Our main dependent variables are the perception of corruption of tax officials and the trust in tax officials from the Afrobarometer survey. Regarding the perception of corruption of tax officials, we refer to question Q53F which asks: "How many of the following people do you think are involved in corruption, or haven't you heard enough about them to say: Tax Officials?". Possible responses are: "None"; "Some of them"; "Most of them"; and "All of them". We code these responses as following: 0 if the response is "None"; 1 if the response is "Some of them"; 2 if it is "Most of them"; and 3 if the answer is "All of them". For the trust in tax officials, we refer to question Q52D where respondents were asked: "How much do you trust each of the following, or haven't you heard enough about them to say: the tax department?". Possible answers include: "Not at all"; "Just a little"; "Somewhat"; and "A lot". We code the different answers as following: 0 if the answer is "Not at all"; 1 if the answer is "Just a little"; 2 if the response is "Somewhat"; and 3 if it is "A lot".

We then use a range of indicators to estimate the effect of digitalization on trust in tax officials and corruption. First, we use the World Bank's Digital Adoption Index (DAI) dataset, year 2014. The DAI is a composite index measuring the extent of spread of digital technologies within and across countries. The aggregate DAI is the simple average of three sectoral subindices covering businesses, people and governments, with each sub-index assigned an equal 
weight. The DAI sub-index for the business sector is the simple average of four normalized indicators: the percentage of business with websites, the number of secure servers, download speed, and $3 \mathrm{G}$ coverage in the country. The DAI sub-index for people is the simple average of two normalized indicators from the Gallup World Poll: mobile access at home and internet access at home. As for the DAI sub-index for the government, it is the simple average of three indicators: core administrative systems, online public services, and digital identification.

Second, we use the World Bank's Open Budget and Public Financial Management (PFM eservices) indices. The open budget index measures the extent to which the government budget data are made accessible to the public (online) in editable (machine-readable) and reusable format, without any restrictions (free/legally open). The PFM e-services index measures the automation and integration of public financial management digital processes including budget formulation, execution, accounting and reporting. These digital tools could include e-filling, e-procurement, digital payroll, and debt management systems.

Third, we use the United Nations data on E-Government, E-Participation and online services index. The E-Government index is a weighted average of three normalized scores, including the scope and quality of online services, the status of the development of telecommunication infrastructure, and the human capital index. The online services component was constructed through a survey on each country's national website and the websites of the related ministries of education, labor, social services, health, finance and environment as applicable. This index is also used separately in our estimates. The telecommunication infrastructure index is the simple average of five indicators, namely the estimated internet users per 100 inhabitants, the number of main fixed telephone lines per 100 inhabitants, the number of mobile subscribers per 100 inhabitants, the number of wireless broadband subscriptions per 100 inhabitants and the number of fixed broadband subscriptions per 100 inhabitants. The human capital component is a weighted average composite of four indicators including adult literacy rate; the combined primary, secondary and tertiary gross enrolment ratio; the expected years of schooling; and the average years of schooling. The E-Participation index is similar to the EGovernment index but focuses on the use of online services to facilitate the provision of information by governments to citizens, interactions with stakeholders and engagement in 
decision-making processes. Third, in robustness checks, we use several indicators of digitalization from the World Bank's World Development Indicators including the use of digital payment methods, the use of mobile phone to pay bills or access a financial institution account, and the use of internet for online services.

For the remaining control variables, we use several variables from the sixth wave of Afrobarometer surveys, including the socio-demographic conditions of respondents (age, education, employment status, gender, living area, wealth), the respondents' assessments of the difficulty to evade taxes or finding which taxes to pay, and the handling by government of various public services (health and education services, living standards, infrastructure, fighting crime). We also control for the respondents' perception of democracy and treatment of own ethnic group compared to the other ethnic groups in the country, their perceived satisfaction of politicians, and media channels (social media and newspapers). Finally, we control for the quality of the business environment using the World Bank's Doing Business database.

\section{B. Empirical strategy}

The empirical method in this paper belongs to the class of multilevel (hierarchical) models. These models are specific to hierarchical data and account for the clustering of data upon different categories (levels). Given that we estimate the effect of digitalization-measured at the country level—on individuals' perception of corruption of tax officials, it is important to account for the hierarchical structure of the data. According to several studies (van den Noortgate et al., 2005; Luke, 2004; Moerbeek, 2004; Tranmer and Steele, 2001), ignoring the hierarchical structure of data, as well as ignoring the higher clustering of data, could lead to misattributed response variation to the already included levels, biased standard errors of the estimates, and wrong conclusions about the covariates' effects.

In this paper, the observed outcomes (corruption of tax officials) are ordinal variables with four degree of intensity: 'None', 'Some of them', 'Most of them', and 'All of them'. With hierarchically structured data, this translates into a hierarchical ordered model (Bryk and Raudenbush, 1992). We use a multilevel ordered probit model with two levels (the individual 
level and the country level) to estimate the effect of digitalization on the perception of corruption of tax officials. Individuals are nested within countries. The advantage of multilevel over OLS methods is to correctly model hierarchical data that do not satisfy the basic assumption of independence of observations. We estimate the following equation:

\section{Corruption $_{i c}=\pi$ Digitalization $_{c}+\beta X_{i c}+\mu_{c}+\varepsilon_{i c}$}

Where Corruption ic $_{\text {ic }}$ represents the level of perception of corruption in tax officials reported by individual $i$ in country $c$. Digitalization ${ }_{c}$ is our independent variable of interest, which is the level of adoption of digitalization of country $c . X_{i c}$ stands for the individual-level characteristics controlled for in the regressions. $\varepsilon_{i c}$ and $\mu_{c}$ represent the unobserved individual and country effects, each assumed to be normally distributed. In addition, we control for religious and ethnic effects in the estimates. The coefficient $\pi$ is our parameter of interest. It captures the impact of digitalization on the perception of corruption of tax officials.

We control for the following variables:

-Socio-demographic indicators and the level of development, including the age, living area (urban), level of education, gender, wealth, and employment status of the respondents. For the living area, we generate a binary variable taking the value of 1 if the respondent lives in an urban area and 0 otherwise. The variable capturing the level of education takes the values from 0 if the individual has no formal education to 9 if $\mathrm{s} / \mathrm{h}$ has some post-graduated education. Regarding the variable wealth, it is a simple average based on whether the respondent has a car, water, latrine and roof materials. We also control for the level of development of countries to ensure that its potential effect is isolated.

-Difficulty of evading taxes: tax avoidance is a major problem in Africa. According to OECD (2018), sub-Saharan Africa has one of the highest ratios of illicit financial flows of any region in the world. The amount lost annually by Africa through illicit financial flows - much of it due to tax evasion - was thought to exceed USD 50 billion in 2015. This inability to fight tax evasion causes a significant loss of government tax revenue, and thereby lower social and public spending. This in turn increase the perception of corruption of policy makers, and 
particularly the tax department in charge of enforcing taxation rules. To capture this effect, we construct a variable varying between 0 and 3 , with higher values representing difficult tax evasion situation. We rely on one survey question asking how easy or difficult it is to avoid paying tax on property that the respondent owns.

-Difficulty of finding which taxes to pay: One cause of tax evasion is the complexity of taxation systems in African countries. Tax laws are subject to regular changes due to a high level of political instability, rendering them uncertain. Negative experiences with such complex taxation systems may spill over into one's overall evaluation of political institutions including the tax department. Consequently, the expected sign of this variable is positive. We rely on the survey question asking how easy or difficult it is to find out what taxes and fees the respondent is supposed to pay to the government and define a variable taking the value of 0 if the answer is "very easy"; 1 if it is easy; 2 if the answer is difficult and 3 if the response is very difficult.

-Delivery of public services: citizens' experience with government through the delivery of public services can affect their trust in public officials. The provision of accessible, efficient and citizen-oriented public services that effectively address the needs and expectations of the public is a core mandate of any government. We include four variables covering essential public services: education and health, the fight against criminality, improving living standards (jobs and access to food), and infrastructure.

- Handling of health and education services: We rely on two questions of the survey asking how well or badly the respondents perceive the government's handling of education needs and basic health services, with responses ranging from very badly (coded 0 ) to very well (coded 3). We then define a composite variable which is the simple average of the respondents' answers to the two questions, varying between 0 and 3 , with higher values meaning good handling of education and health issues by the government.

- Fight against criminality: one question asked the survey participants how well or badly they assess the government's handling of reducing crime and possible answers include "very badly"; "fairly badly"; "fairly well"; and "very well". The values of the defined variable capturing the fight against criminality by the government range from 0 if the 
answer is "very badly" to 3 if it is "very well".

- Infrastructure: we combine three survey questions asking about the government provision of water and sanitation, roads and electricity infrastructure. The respondents are asked to rate the government handling of infrastructure provision and, as above, possible answers range from "very badly" to "very well". We define a composite indicator which is the simple average of the respondents' answers to the three questions, with higher values representing good provision of infrastructure.

- Improving living standards: we rely on three survey questions asking about rating the government policies to create jobs, improving living standards and ensuring enough food to eat. The possible answers include: "very badly"; "fairly badly"; "fairly well"; and "very well", which we code, respectively, 0, 1,2 and 3. We then define a composite variable which is the simple average of the respondents' answers to the three questions, with higher values representing a good assessment of the government actions to improve living standards.

-Unfair treatment of own ethnic group: to capture the fairness and inclusiveness of government actions, we include this variable related to the respondents' perception of treatment of his/her own ethnic by the government. The consistent treatment of citizens in the policy-making and policy-implementation processes should be guaranteed by any governments. However, ethnic tensions (Montalvo and Reynal-Querol, 2005) often lead to the exclusion of some populations from access to public services and offices. Such situations can potentially negatively affect people's assessment of public officials. We rely on one question of the survey asking how often the respondent ethnic group was treated unfairly by the government, with possible answers including "never", "sometimes", "often", and "always". We code the variable as follows: 0 if the answer is "never"; 1 if it is "sometimes"; 2 if the answer is "often"; and 3 if the answer is "always".

-Democracy: it has been shown in the literature that democracy promotes trust by enhancing citizens' control of and influence on political authorities (Brehm and Rahn, 1997; Levi, 1998). To control for the effect of democracy, we rely on one question of the survey asking whether the respondent is satisfied with democracy in the country and define a variable taking the value of 0 if the answer is "the country is not a democracy"; 1 if it is "not at all satisfied"; 2 if the 
answer is "not very satisfied"; 3 if the answer is "fairly satisfied"; and 4 is the answer is "very satisfied".

-Satisfaction with politicians: When one citizen is unsatisfied with the political system or the government, one would assume that his/her support for these same institutions decreases (Hudson 2006; Mishler and Rose, 2005). To capture this effect, we rely on the survey questions asking whether the respondent approves or disapproves the way the President, the Members of Parliament and the local government councilor are performing their jobs, with possible answers being "strongly disapprove"; "disapprove"; "approve"; and "strongly approve". The values of the coded variable vary between 0 if the answer is "strongly disapprove" and 3 if the answer is "strongly approve". We expect a negative relationship between satisfaction with politicians and perception of corruption of tax officials.

-Media channels: the media gives governments an opportunity to be more transparent and be engaged with the public by keeping them informed about the policy and issues that matter most to them. The media allows organizations to get a real-time view of not only what is happening but, in the case of the public sector, what they can do to help the public that they serve. However, the media can also amplify or even incite national prejudices or tensions when it is used to float various kinds of false reports aimed at tarnishing the image of a group of the population. Therefore, the expected sign for the media channels variable is unclear. We include two media channels: newspapers and social media, with each variable taking the value of 1 if it is used by the respondent to get news, and 0 otherwise.

-Oil deposits: we use this variable to capture the role of natural resources endowments. Resource rents induce rent-seeking as individuals compete for a share of the rents and induce patronage as governments pay off supporters to stay in power, resulting in reduced accountability and an inferior allocation of public funds (Kolstad and Soreide, 2009). Using onshore petroleum site data from the United States Geological Society (United States Geological Survey (USGS, 2014), we define a dummy variable taking the value of 1 if the respondent is living in an area where there is a petroleum site, and 0 otherwise. A positive relationship is expected between the presence of oil deposits and perception of corruption of tax officials. 


\section{Stylized facts}

In figure 1, we present the statistics for the variable perception of corruption of tax officials and the relationship between the overall DAI and the corruption of tax officials. As can be seen, there is a very high perception of corruption of tax officials in Africa as around 9 out of 10 persons surveyed respond that tax officials are corrupt in some way (Panel A). Also, there is a strong negative association between digital adoption and corruption of tax officials (Panel B). Figure 2 shows the averaged values of digital adoption indices for each category of answer regarding corruption of tax officials. Irrespective of the type of digital adoption sub-index, we observe that the level of digitalization is the lowest when people report that all or most of tax officials are corrupted.

Figure 1: Relationship between digital adoption and corruption of tax officials

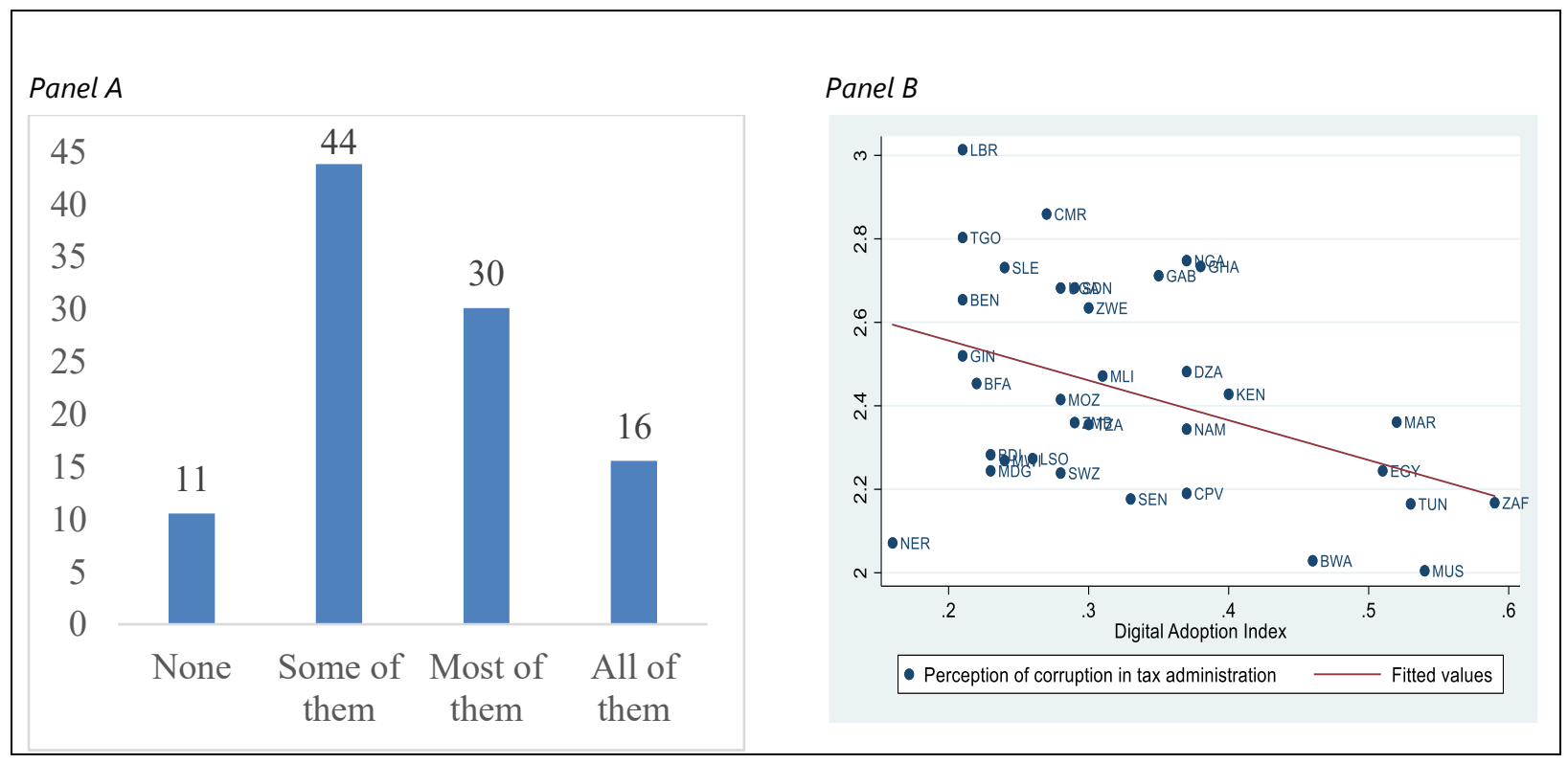


Figure 2: Digitalization and Corruption of Tax Officials
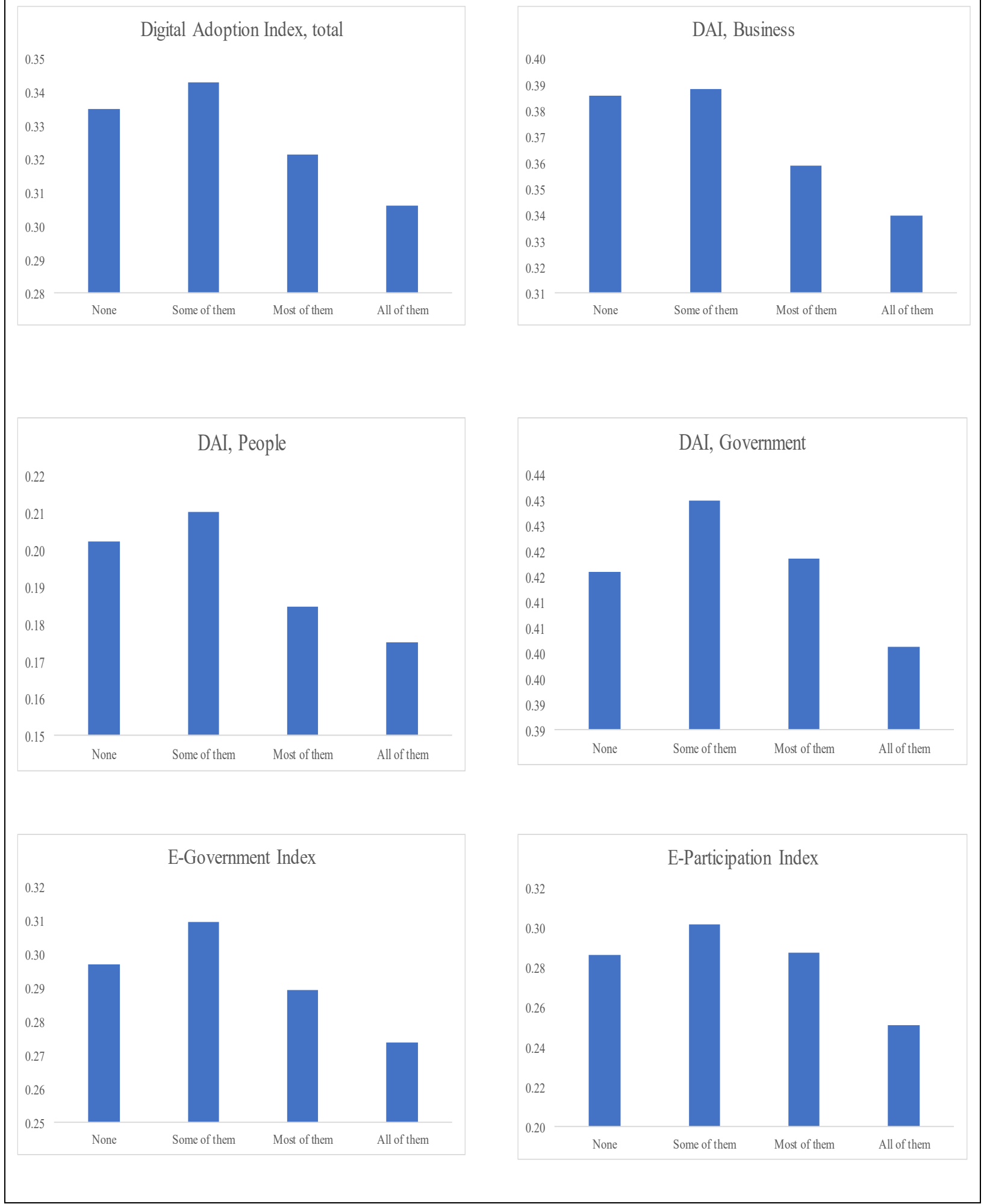

CInternational Monetary Fund. Not for Redistribution 
Figure 3 presents the statistics for the variable trust in the tax department and the relationship between the overall digital adoption index and trust in tax officials. Only 1 out 5 individuals surveyed have full trust in tax officials, which suggest that mistrust in tax departments seems to be common in Africa (Panel A). Figure 3 also shows a positive correlation between digitalization and trust in tax official, with highly digitalized economies benefiting from strong trust in tax officials (Panel B). On the contrary, trust in tax officials is lower in countries with low digital adoption index. We plot in Figure 4 the average of several digital adoption indices for each category of responses regarding the trust in tax official. We observe that, on average, the lowest digital adoption when people do not trust at all tax officials.

Figure 3: Relationship between trust in tax official and digitalization

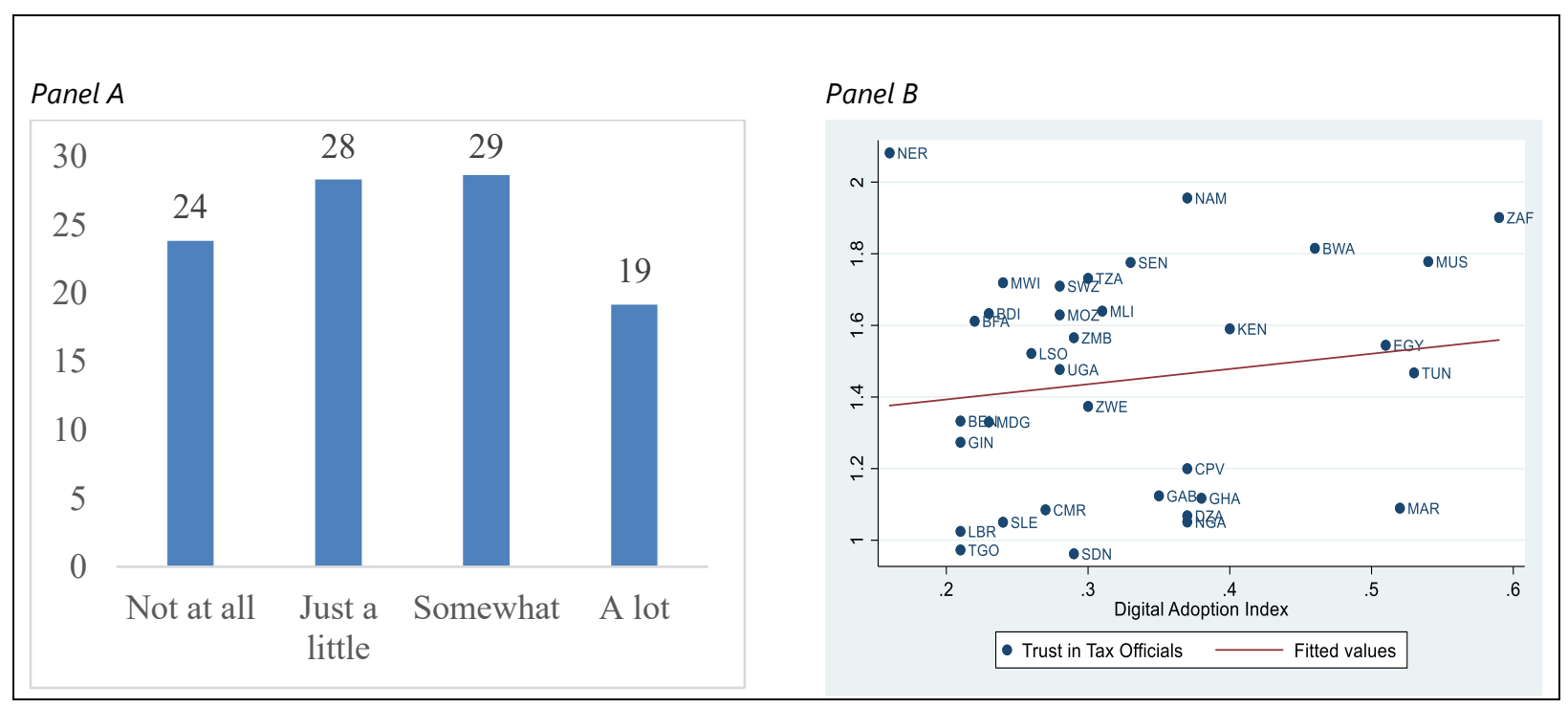




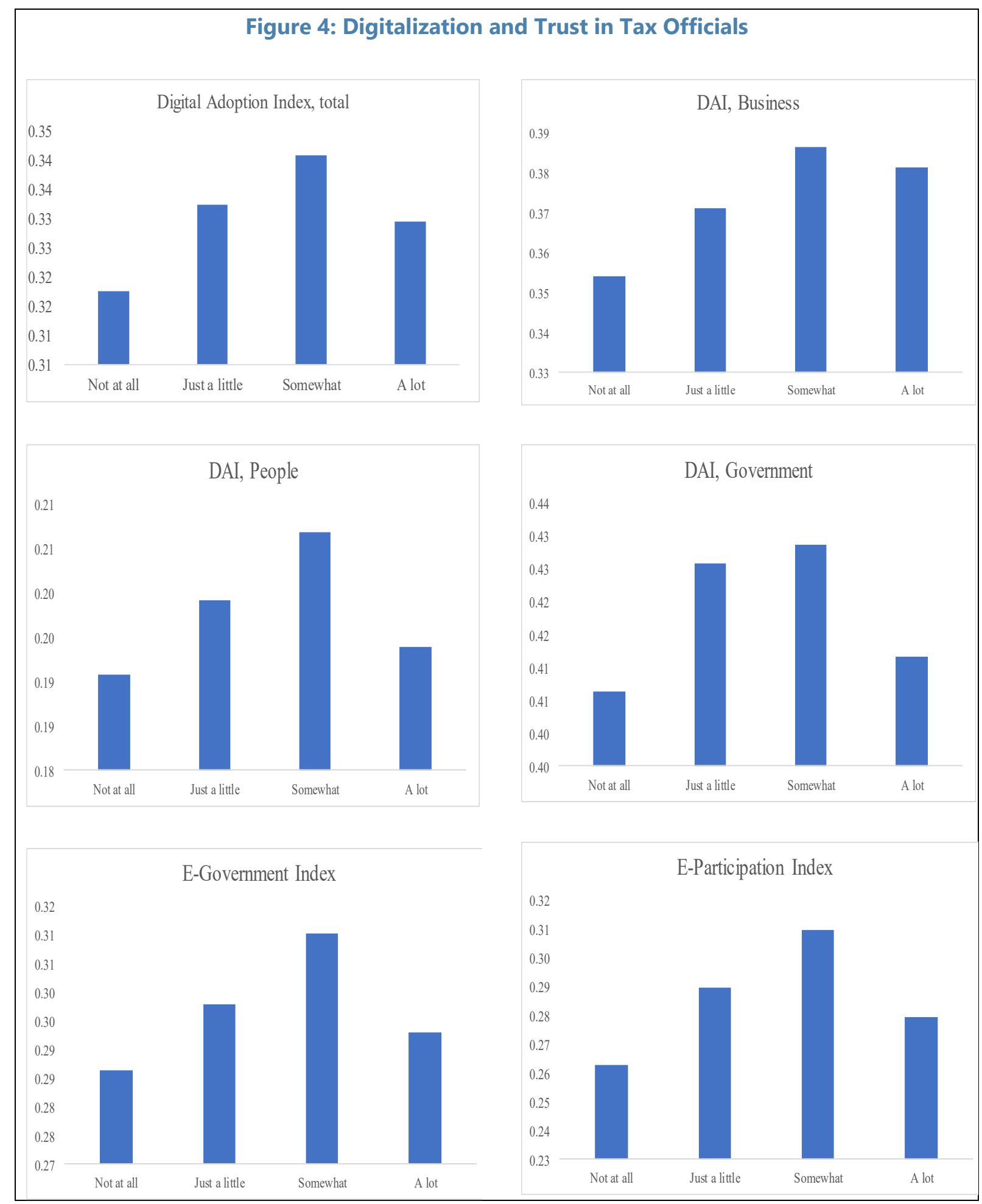

CInternational Monetary Fund. Not for Redistribution 


\section{RESULTS}

\section{A. Baseline results}

Table 1 reports the baseline results for various indicators of digitalization. Note that all tables present the coefficients of the variables. From the outset, we observe that in all columns, our coefficient of interest is negative and strongly significant at the 1 percent level, suggesting that greater digital adoption is correlated with lower perception of corruption in tax officials.

In column (1), we estimate equation (1) with the aggregate index of digitalization adoption as dependent variable. The coefficient associated with this aggregate index is positive and significant at the 1 percent level. This result suggests that digitalization is negatively correlated with the level of perception of corruption of tax officials. Quantitatively, Table 1 shows that an increase in the index of digital adoption from the first quartile to the third quartile is associated with a decline in the probability that respondents assess that all tax officials are corrupt from 11.2 to 7.5 percentage points ${ }^{1}$, while the probability that respondents assess that any tax officials are corruption increase from 11.7 to 16.7 percentage points.

In columns 2-4, we disaggregate the index of digital adoption into three sub-indices based on the type of adopters: people, business, and government. We observe that the coefficient associated with the three sub-indices is still negative and strongly significant at the 1 percent level. Moreover, the coefficient associated with DAI for business is higher than the remaining sub-indices, suggesting that the impact of digitalization on in the perception of corruption of tax officials is higher for companies than for the other digital adopters.

In columns 5 and 6 we use the E-Government and E-Participation indices. We still observe that the coefficient associated with the two variables are negative and significant at the 1 percent level. In column 7 we use index of online services, which is a sub-index of the EGovernment index. We find a negative correlation between online services and corruption perception in tax officials. Finally, we focus on the specific use of digital tools in public finances by employing the open budget index and the PFM e-services index. The results are

\footnotetext{
${ }^{1}$ These are estimated marginal effects at the mean values.
} 
reported in columns 8 and 9. They shed light that there is a negative correlation between the online openness of the budget process to the public, the employment of e-services in public finances and the perception of corruption of tax officials.

Table 1: Digitalization and corruption

\begin{tabular}{|c|c|c|c|c|c|c|c|c|c|}
\hline \multirow[b]{3}{*}{ VARIABLES } & \multirow{2}{*}{\multicolumn{4}{|c|}{ Digital Adoption Index (DAI) }} & \multirow{3}{*}{$\begin{array}{c}\text { (5) } \\
\text { E-Government } \\
\text { Index }\end{array}$} & \multirow{3}{*}{\begin{tabular}{c|}
$(6)$ \\
E-Participation \\
Index \\
\end{tabular}} & \multirow{3}{*}{\begin{tabular}{|c|} 
(7) \\
Online \\
Service Index \\
\end{tabular}} & \multirow{3}{*}{$\begin{array}{c}(8) \\
\text { Open budget }\end{array}$} & \multirow{3}{*}{$\begin{array}{c}(9) \\
\text { PFM e- } \\
\text { services }\end{array}$} \\
\hline & & & & & & & & & \\
\hline & Aggregate DAI & DAI Business & DAI People & DAI Government & & & & & \\
\hline Digitalization & $\begin{array}{c}-2.2141 * * * \\
(0.452)\end{array}$ & $\begin{array}{c}-2.0583^{* * *} \\
(0.318)\end{array}$ & $\begin{array}{c}-1.5743^{* * *} \\
(0.442)\end{array}$ & $\begin{array}{c}-0.5642 * * * \\
(0.195)\end{array}$ & $\begin{array}{c}-1.4708^{* * *} \\
(0.364)\end{array}$ & $\begin{array}{c}-0.6056^{* * *} \\
(0.153)\end{array}$ & $\begin{array}{c}-0.7617^{* * *} \\
(0.194)\end{array}$ & $\begin{array}{c}-0.8312^{* * *} \\
(0.156)\end{array}$ & $\begin{array}{c}-1.3004 * * * \\
(0.264)\end{array}$ \\
\hline Age, $<25$ & $\begin{array}{c}-0.0278 \\
(0.031)\end{array}$ & $\begin{array}{r}-0.0277 \\
(0.031)\end{array}$ & $\begin{array}{c}-0.0280 \\
(0.031)\end{array}$ & $\begin{array}{r}-0.0275 \\
(0.031)\end{array}$ & $\begin{array}{r}-0.0163 \\
(0.030)\end{array}$ & $\begin{array}{r}-0.0162 \\
(0.030)\end{array}$ & $\begin{array}{r}-0.0161 \\
(0.030)\end{array}$ & $\begin{array}{r}-0.0197 \\
(0.031)\end{array}$ & $\begin{array}{r}-0.0193 \\
(0.031)\end{array}$ \\
\hline Age, $>25$ & $\begin{array}{l}0.0232 \\
(0.027)\end{array}$ & $\begin{array}{l}0.0241 \\
(0.027)\end{array}$ & $\begin{array}{l}0.0233 \\
(0.027)\end{array}$ & $\begin{array}{l}0.0229 \\
(0.027)\end{array}$ & $\begin{array}{l}0.0349 \\
(0.026)\end{array}$ & $\begin{array}{l}0.0349 \\
(0.026)\end{array}$ & $\begin{array}{l}0.0349 \\
(0.026)\end{array}$ & $\begin{array}{l}0.0334 \\
(0.027)\end{array}$ & $\begin{array}{l}0.0331 \\
(0.027)\end{array}$ \\
\hline Urban & $\begin{array}{l}0.0273 \\
(0.019)\end{array}$ & $\begin{array}{l}0.0287 \\
(0.019)\end{array}$ & $\begin{array}{l}0.0294 \\
(0.019)\end{array}$ & $\begin{array}{l}0.0264 \\
(0.019)\end{array}$ & $\begin{array}{l}0.0188 \\
(0.018)\end{array}$ & $\begin{array}{l}0.0189 \\
(0.018)\end{array}$ & $\begin{array}{l}0.0190 \\
(0.018)\end{array}$ & $\begin{array}{l}0.0212 \\
(0.019)\end{array}$ & $\begin{array}{l}0.0206 \\
(0.019)\end{array}$ \\
\hline Education & $\begin{array}{l}0.0072 \\
(0.005)\end{array}$ & $\begin{array}{l}0.0071 \\
(0.005)\end{array}$ & $\begin{array}{l}0.0068 \\
(0.005)\end{array}$ & $\begin{array}{l}0.0069 \\
(0.005)\end{array}$ & $\begin{array}{l}0.0045 \\
(0.005)\end{array}$ & $\begin{array}{l}0.0042 \\
(0.005)\end{array}$ & $\begin{array}{l}0.0042 \\
(0.005)\end{array}$ & $\begin{array}{l}0.0033 \\
(0.005)\end{array}$ & $\begin{array}{l}0.0035 \\
(0.005)\end{array}$ \\
\hline Wealth & $\begin{array}{l}0.0195 \\
(0.022)\end{array}$ & $\begin{array}{l}0.0189 \\
(0.022)\end{array}$ & $\begin{array}{l}0.0193 \\
(0.022)\end{array}$ & $\begin{array}{l}0.0168 \\
(0.022)\end{array}$ & $\begin{array}{l}0.0206 \\
(0.021)\end{array}$ & $\begin{array}{l}0.0209 \\
(0.021)\end{array}$ & $\begin{array}{l}0.0215 \\
(0.021)\end{array}$ & $\begin{array}{l}0.0207 \\
(0.021)\end{array}$ & $\begin{array}{l}0.0232 \\
(0.021)\end{array}$ \\
\hline Employment & $\begin{array}{c}0.0448 * * \\
(0.017)\end{array}$ & $\begin{array}{c}0.0427 * * \\
(0.017)\end{array}$ & $\begin{array}{c}0.0406^{* *} \\
(0.017)\end{array}$ & $\begin{array}{c}0.0443^{* *} \\
(0.017)\end{array}$ & $\begin{array}{c}0.0459 * * * \\
(0.017)\end{array}$ & $\begin{array}{c}0.0462 * * * \\
(0.017)\end{array}$ & $\begin{array}{c}0.0458 * * * \\
(0.017)\end{array}$ & $\begin{array}{c}0.0486^{* * *} \\
(0.017)\end{array}$ & $\begin{array}{c}0.0490 * * * \\
(0.017)\end{array}$ \\
\hline Male & $\begin{array}{l}0.0035 \\
(0.015)\end{array}$ & $\begin{array}{l}0.0036 \\
(0.015)\end{array}$ & $\begin{array}{l}0.0041 \\
(0.015)\end{array}$ & $\begin{array}{l}0.0044 \\
(0.015)\end{array}$ & $\begin{array}{l}0.0068 \\
(0.015)\end{array}$ & $\begin{array}{l}0.0070 \\
(0.015)\end{array}$ & $\begin{array}{l}0.0069 \\
(0.015)\end{array}$ & $\begin{array}{l}0.0064 \\
(0.015)\end{array}$ & $\begin{array}{l}0.0063 \\
(0.015)\end{array}$ \\
\hline Difficulty of evading taxes & $\begin{array}{l}-0.0113 \\
(0.010)\end{array}$ & $\begin{array}{l}-0.0101 \\
(0.010)\end{array}$ & $\begin{array}{l}-0.0114 \\
(0.010)\end{array}$ & $\begin{array}{l}-0.0119 \\
(0.010)\end{array}$ & $\begin{array}{l}-0.0013 \\
(0.009)\end{array}$ & $\begin{array}{l}-0.0012 \\
(0.009)\end{array}$ & $\begin{array}{r}-0.0013 \\
(0.009)\end{array}$ & $\begin{array}{c}-0.0014 \\
(0.010)\end{array}$ & $\begin{array}{l}-0.0017 \\
(0.010)\end{array}$ \\
\hline Handling of health and education services & $\begin{array}{r}-0.0157 \\
(0.013)\end{array}$ & $\begin{array}{r}-0.0150 \\
(0.013)\end{array}$ & $\begin{array}{r}-0.0156 \\
(0.013)\end{array}$ & $\begin{array}{c}-0.0149 \\
(0.013)\end{array}$ & $\begin{array}{l}-0.0121 \\
(0.012)\end{array}$ & $\begin{array}{l}-0.0127 \\
(0.012)\end{array}$ & $\begin{array}{l}-0.0128 \\
(0.012)\end{array}$ & $\begin{array}{l}-0.0161 \\
(0.013)\end{array}$ & $\begin{array}{l}-0.0158 \\
(0.013)\end{array}$ \\
\hline Infrastructure & $\begin{array}{c}-0.0399 * * * \\
(0.015)\end{array}$ & $\begin{array}{c}-0.0398^{* * *} \\
(0.015)\end{array}$ & $\begin{array}{c}-0.0417 * * * \\
(0.015)\end{array}$ & $\begin{array}{c}-0.0431 * * * \\
(0.015)\end{array}$ & $\begin{array}{c}-0.0149 \\
(0.014)\end{array}$ & $\begin{array}{l}-0.0147 \\
(0.014)\end{array}$ & $\begin{array}{r}-0.0145 \\
(0.014)\end{array}$ & $\begin{array}{l}-0.0157 \\
(0.014)\end{array}$ & $\begin{array}{l}-0.0157 \\
(0.014)\end{array}$ \\
\hline Reducing crime & $\begin{array}{c}-0.0814 * * * \\
(0.014)\end{array}$ & $\begin{array}{c}-0.0822 * * * \\
(0.014)\end{array}$ & $\begin{array}{c}-0.0801 * * * \\
(0.014)\end{array}$ & $\begin{array}{c}-0.0795 * * * \\
(0.014)\end{array}$ & $\begin{array}{c}-0.1006^{* * *} \\
(0.013)\end{array}$ & $\begin{array}{c}-0.1003^{* * *} \\
(0.013)\end{array}$ & $\begin{array}{c}-0.1000^{* * *} \\
(0.013)\end{array}$ & $\begin{array}{c}-0.0989^{* * *} \\
(0.013)\end{array}$ & $\begin{array}{c}-0.0990^{* * *} \\
(0.013)\end{array}$ \\
\hline Handling of improving living standards & $\begin{array}{c}-0.0954 * * * \\
(0.016)\end{array}$ & $\begin{array}{c}-0.0957^{* * *} \\
(0.016)\end{array}$ & $\begin{array}{c}-0.0953 * * * \\
(0.016)\end{array}$ & $\begin{array}{c}-0.0962 * * * \\
(0.016)\end{array}$ & $\begin{array}{c}-0.1113^{* * *} \\
(0.015)\end{array}$ & $\begin{array}{c}-0.1114^{* * *} \\
(0.015)\end{array}$ & $\begin{array}{c}-0.1112^{* * *} \\
(0.015)\end{array}$ & $\begin{array}{c}-0.1067^{* * *} \\
(0.015)\end{array}$ & $\begin{array}{c}-0.1064 * * * \\
(0.015)\end{array}$ \\
\hline Unfair treatment of own ethnic group & $\begin{array}{c}0.0842 * * * \\
(0.009)\end{array}$ & $\begin{array}{c}0.0835^{* * *} \\
(0.009)\end{array}$ & $\begin{array}{c}0.0836 * * * \\
(0.009)\end{array}$ & $\begin{array}{c}0.0835^{* * *} \\
(0.009)\end{array}$ & $\begin{array}{c}0.0782 * * * \\
(0.009)\end{array}$ & $\begin{array}{c}0.0781 * * * \\
(0.009)\end{array}$ & $\begin{array}{c}0.0784 * * * \\
(0.009)\end{array}$ & $\begin{array}{c}0.0781 * * * \\
(0.009)\end{array}$ & $\begin{array}{c}0.0789 * * * \\
(0.009)\end{array}$ \\
\hline Democracy & $\begin{array}{c}-0.0839 * * * \\
(0.009)\end{array}$ & $\begin{array}{c}-0.0845^{* * *} \\
(0.009)\end{array}$ & $\begin{array}{c}-0.0845^{* * *} * \\
(0.009)\end{array}$ & $\begin{array}{c}-0.0847 * * * \\
(0.009)\end{array}$ & $\begin{array}{c}-0.0884^{* * *} \\
(0.008)\end{array}$ & $\begin{array}{c}-0.0881^{* * *} \\
(0.008)\end{array}$ & $\begin{array}{c}-0.0881^{* * *} \\
(0.008)\end{array}$ & $\begin{array}{c}-0.0884 * * * \\
(0.009)\end{array}$ & $\begin{array}{c}-0.0879 * * * \\
(0.009)\end{array}$ \\
\hline Satisfaction with politicians & $\begin{array}{c}-0.2034^{* * *} \\
(0.012)\end{array}$ & $\begin{array}{c}-0.2016^{* * *} \\
(0.012)\end{array}$ & $\begin{array}{c}-0.2028 * * * \\
(0.012)\end{array}$ & $\begin{array}{c}-0.2024 * * * \\
(0.012)\end{array}$ & $\begin{array}{c}-0.1994 * * * \\
(0.012)\end{array}$ & $\begin{array}{c}-0.1992^{* * *} \\
(0.012)\end{array}$ & $\begin{array}{c}-0.1994^{* * *} \\
(0.012)\end{array}$ & $\begin{array}{c}-0.1937^{* * *} * \\
(0.012)\end{array}$ & $\begin{array}{c}-0.1951^{* * *} \\
(0.012)\end{array}$ \\
\hline Difficulty of finding which taxes to pay & $\begin{array}{c}0.0702 * * * \\
(0.009)\end{array}$ & $\begin{array}{c}0.0697^{* * *} \\
(0.009)\end{array}$ & $\begin{array}{c}0.0703 * * * \\
(0.009)\end{array}$ & $\begin{array}{c}0.0717^{* * *} \\
(0.009)\end{array}$ & $\begin{array}{c}0.0656^{* * *} \\
(0.009)\end{array}$ & $\begin{array}{c}0.0655^{* * *} \\
(0.009)\end{array}$ & $\begin{array}{c}0.0653^{* * *} \\
(0.009)\end{array}$ & $\begin{array}{c}0.0673^{* * *} \\
(0.009)\end{array}$ & $\begin{array}{c}0.0674 * * * \\
(0.009)\end{array}$ \\
\hline Media & $\begin{array}{c}0.0762 * * * \\
(0.025)\end{array}$ & $\begin{array}{c}0.0768^{* * *} \\
(0.025)\end{array}$ & $\begin{array}{c}0.0738^{* * *} \\
(0.025)\end{array}$ & $\begin{array}{c}0.0699^{* * *} \\
(0.025)\end{array}$ & $\begin{array}{c}0.0903 * * * \\
(0.024)\end{array}$ & $\begin{array}{c}0.0902 * * * \\
(0.024)\end{array}$ & $\begin{array}{c}0.0906^{* * *} \\
(0.024)\end{array}$ & $\begin{array}{c}0.0831^{* * *} \\
(0.024)\end{array}$ & $\begin{array}{c}0.0834 * * * \\
(0.024)\end{array}$ \\
\hline Oil deposits & $\begin{array}{c}0.2682 * * \\
(0.107)\end{array}$ & $\begin{array}{l}0.1285 \\
(0.108)\end{array}$ & $\begin{array}{c}0.2016^{*} \\
(0.111)\end{array}$ & $\begin{array}{c}0.3036^{* * * *} \\
(0.114)\end{array}$ & $\begin{array}{c}0.2497 * * \\
(0.107)\end{array}$ & $\begin{array}{c}0.2990^{* * * *} \\
(0.107)\end{array}$ & $\begin{array}{c}0.2998 * * * \\
(0.107)\end{array}$ & $\begin{array}{c}0.2723 * * \\
(0.124)\end{array}$ & $\begin{array}{c}0.3753 * * * \\
(0.125)\end{array}$ \\
\hline GDP per capita, log & $\begin{array}{c}-0.0993^{*} \\
(0.058)\end{array}$ & $\begin{array}{c}-0.0770^{*} \\
(0.046)\end{array}$ & $\begin{array}{l}0.0673 \\
(0.066)\end{array}$ & $\begin{array}{l}0.0424 \\
(0.061)\end{array}$ & $\begin{array}{l}0.0214 \\
(0.051)\end{array}$ & $\begin{array}{c}-0.0897 * * \\
(0.036)\end{array}$ & $\begin{array}{c}-0.0687^{*} \\
(0.038)\end{array}$ & $\begin{array}{l}-0.0301 \\
(0.042)\end{array}$ & $\begin{array}{c}-0.1287 * * * \\
(0.037)\end{array}$ \\
\hline Observations & 21,866 & 21,866 & 21,866 & 21,866 & 23,752 & 23,752 & 23,752 & 23,007 & 23,007 \\
\hline Number of regions & 301 & 301 & 301 & 301 & 334 & 334 & 334 & 310 & 310 \\
\hline Number of countries & 26 & 27 & 28 & 29 & 30 & 31 & 32 & 32 & 32 \\
\hline Region fixed effects & Yes & Yes & Yes & Yes & Yes & Yes & Yes & Yes & Yes \\
\hline Ethnicity fixed effects & Yes & Yes & Yes & Yes & Yes & Yes & Yes & Yes & Yes \\
\hline Religion fixed effects & Yes & Yes & Yes & Yes & Yes & Yes & Yes & Yes & Yes \\
\hline
\end{tabular}

Regarding the control variables, our results are broadly in line with expectations. The coefficients associated with the government handling of improving living standards and reducing crime are all negative and strongly significant at 1 percent level in all columns. Thus, 
the perception of corruption in tax officials is lower in countries where the government handles better social, employment and crime issues. Similarly, the availability of infrastructure, high perception of democracy in the country, and satisfaction with politicians are correlated with lower perception of corruption in tax officials. These results are in line with the theory of fiscal exchanges according to which the provision of goods and services by the government enhances rules compliance and trust in government actions (Ali, Fjeldstad and Sjursen, 2014; More, 2004).

In contrast, the coefficient associated with the perception of unfair treatment of own ethnic group and difficulty in finding which taxes to pay are negatively associated with the perception of corruption of tax officials. As the theory of comparative treatment suggests, citizens compliance with rules and perception in public officials are likely to be affected when they perceive the system that determines those rules to be partial in some ways, such as unfairness toward an ethnic group (Ali, Fjeldstad and Sjursen, 2014; McKerchar and Evans, 2009).

As expected, a complex taxation system boosts the perception of corruption of tax officials as a long time taken to find out which taxes to pay increases frustrations and potentially reduces satisfaction with government services. In line with previous studies, we find that the coefficient associated with oil deposits is positive and significant, suggesting that the perception of corruption of tax officials is high in areas with oil deposits. The remaining control variables are not statistically significant.

\section{B. Robustness checks}

We undertake several robustness exercises, including using alternative indicators of digital adoption, an alternative econometric method and the inclusion of more macro variables.

\section{(i) Use of alternative indicators of digital adoption}

We use various alternative indicators of digitalization from the World Bank's Global Findex

Database. Table 2 reports the results obtained when we proxy digital adoption using digital payment methods. In column (1) we focus on the percentage of the population aged $15+$ who 
received or sent digital payments. The subsequent columns split the share of the population aged $15+$ into those who exclusively made digital payments (columns 2), and those who received digital payments (column 3 and 4). As shown by the coefficient associated with digital payments, we still detect a negative and significant effect of digitalization on the perception of corruption of government officials. Based on column (1), an increase of the share of the population aged $15+$ using digital payments from the first quartile (19 percent of the population) to the third quartile (41.5 percent of the population) is correlated with a decline in the perceived level of corruption of all tax officials from 15.5 percent to 13.1 percent.

In Table 3, we use some indicators related to the use of mobile phone for bill payments. Mobile money has been increasing in recent years in sub-Saharan Africa (IMF 2019c). In column (12) we use the share of the population aged 15+ who used mobile phone to pay utility bills, while in columns (3-5) we rely on the use of the mobile phone to receive wage payments. In column (6), the share of the population aged 15+ using mobile phone to pay school fees is used. As for columns 7-9, we look at the use of mobile phone to receive payments for agricultural products, self-employment payments, and government payments. In column (10), we rely on the share of the population aged 15+ owing a mobile phone account. The results in Table 3 show that the coefficient associated with our variable of interest-use of mobile phone-is not statistically significant in all columns, except in column (7). The finding suggests that the sole use of mobile phones for payments is not yet a strong deterrent of the perception of corruption of tax officials in Africa. This could be explained by the fact that mobile phones are mostly used for simple payments services in Africa and do not allow for a broad usage of internet or fact-checking services. To have an impact on the perception of corruption, additional elements of digitalization beyond payments such as the use of internet may be needed.

To check whether the use of internet would matter, we report in Table 4 the results obtained by running equation (1) and employing the use of internet as a proxy of digitalization. In columns 1 and 2 we focus on the use of internet among the population aged 15+ and 25+, respectively, to pays bills, while columns 3 and 4 are broadly about those who use internet to pay bills or to buy something among the same segments of the population. The effect of the 
use of internet on the perception of corruption of tax officials is negative and strongly significant in all columns. In Table 5, we combine the use of mobile phone and the Internet. The results do not change.

\section{(ii) Using an alternative econometric method-Lewbel (2012)}

In this section, we use an alternative empirical method to tackle the endogeneity concern. In fact, one could argue that corruption and the legitimacy of tax officials can in turn affect the degree of digital adoption. For instance, corrupted or untrusted officials can delay the adoption of structural reforms necessary to speed up digitalization or may not be keen to promote digitalization as it could be used as a checking tool of their actions. To address this issue of endogeneity, we apply an estimator proposed by Lewbel (2012) which is a heteroskedasticity based instrumental variable approach. This method uses heteroskedasticity to identify and estimate mis-measured and endogenous regressor models. Reliance on instrumental variable (IV) methods usually requires that appropriate exogeneous instruments are available to identify the model, which is subject of debate in the literature. Here, we use the heteroscedasticity based instrumental variable approach as an alternative IV method to check the robustness of our results.

The method proposed by Lewbel (2012) uses internal instruments and serves to identify parameters in regression models with endogenous or mismeasured regressors in the absence of traditional identifying information, such as external and exogeneous instruments. It identifies the parameters through imposing a heteroscedastic covariance restriction on the disturbances. Table 6 reports the results obtained using Lewbel (2012)'s method. We find that the coefficients associated with digitalization are still consistent and aligned with those of Table 1. Thus, using an alternative econometric method does not change the findings of the paper.

\section{(iii) Including more covariates}

Finally, we check for omitted variables issue by including additional controls. We re-estimate the association between digitalization, trust in tax officials and corruption including several 
control variables. We include some macroeconomic variables such as economic growth, inflation, civil war, and the poverty rate, and one governance related variable - rule of lawextracted from the World Bank's Worldwide Governance Indicators database. Difficult economic and security conditions and poverty can affect the populations assessment of public officials. Table 7 reports the results when all these macroeconomic control variables are considered. We find that the results are quite consistent with our baseline findings in Table 1. As expected, the coefficients associated with rule of law are negatively associated with high level of corruption perception.

\section{Digitalization AND TRUST IN TAX OFFICIALS}

In this section, we explore whether digitalization improves trust in tax officials, thus reducing the perception of corruption that we described in Section 4.A. The use of digital tools helps create more direct channels of feedback and communication between citizens and government, reducing the opacity of government transactions and promoting trust. To test this hypothesis, we estimate the effect of digitalization on the perceived level of trust in tax officials using the same specification in Table 1. The results are reported in Table 8. As can observed, the coefficients associated with the different indicators of digital adoption are positive and highly significant at 1 percent level, except in column (4). Considering column 1 where we use the aggregate index of digital adoption, an increase in the index from the first quartile to the third quartile is associated with an increase in the perceived trust in all tax officials from 14 percent to 17.8 percent. At the same time, the probability that none of the tax officials is trusted declines from 23.5 percent to 18.9 percent.

Looking at the disaggregated indices, we find that the coefficients associated with all of them are positive and strongly significant at 1 percent level. As in Table 1, the coefficient associated with the digital adoption by the business sector is higher than those of the government and

people. Regarding the indicators of e-government, e-participation, use of online services, the open budget index and PFM e-services, the coefficients associated with them are all positive and significant, and in line with expectations. 
Table 8: Digitalization and trust in tax officials

\begin{tabular}{|c|c|c|c|c|c|c|c|c|c|}
\hline \multirow[b]{3}{*}{ VARIABLES } & $(1)$ & $(2)$ & (3) & (4) & $(5)$ & $(6)$ & $(7)$ & $(8)$ & (9) \\
\hline & \multicolumn{4}{|c|}{ Digital Adoption Index (DAI) } & \multirow{2}{*}{$\begin{array}{c}\text { E-Government } \\
\text { Index }\end{array}$} & \multirow{2}{*}{$\begin{array}{c}\text { E-Participation } \\
\text { Index }\end{array}$} & \multirow{2}{*}{$\begin{array}{c}\text { Online } \\
\text { Service Index }\end{array}$} & \multirow{2}{*}{ Open budget } & \multirow{2}{*}{$\begin{array}{l}\text { PFM e- } \\
\text { services }\end{array}$} \\
\hline & Aggregate & DAI Business & DAI People & DAI Government & & & & & \\
\hline Digitalization & $\begin{array}{c}1.5325^{* * *} \\
(0.389)\end{array}$ & $\begin{array}{c}1.2968^{* * * *} \\
(0.277)\end{array}$ & $\begin{array}{c}0.7776^{* *} \\
(0.381)\end{array}$ & $\begin{array}{c}0.2786^{*} \\
(0.126)\end{array}$ & $\begin{array}{c}0.7482 * * \\
(0.315)\end{array}$ & $\begin{array}{c}0.3453 * * * \\
(0.133)\end{array}$ & $\begin{array}{c}0.4455^{* * *} \\
(0.169)\end{array}$ & $\begin{array}{c}0.5962 * * * \\
(0.125)\end{array}$ & $\begin{array}{c}0.8650 * * * \\
(0.213)\end{array}$ \\
\hline Age, $<25$ & $\begin{array}{c}-0.0622^{* *} \\
(0.031)\end{array}$ & $\begin{array}{c}-0.0622^{* *} \\
(0.031)\end{array}$ & $\begin{array}{c}-0.0620^{* *} \\
(0.031)\end{array}$ & $\begin{array}{c}-0.0623 * * \\
(0.031)\end{array}$ & $\begin{array}{c}-0.0595 * * \\
(0.030)\end{array}$ & $\begin{array}{c}-0.0596^{* *} \\
(0.030)\end{array}$ & $\begin{array}{c}-0.0597 * * \\
(0.030)\end{array}$ & $\begin{array}{c}-0.0596 * * \\
(0.030)\end{array}$ & $\begin{array}{c}-0.0598 * * \\
(0.030)\end{array}$ \\
\hline Age, $>25$ & $\begin{array}{l}-0.0424 \\
(0.027)\end{array}$ & $\begin{array}{l}-0.0429 \\
(0.027)\end{array}$ & $\begin{array}{c}-0.0424 \\
(0.027)\end{array}$ & $\begin{array}{r}-0.0421 \\
(0.027)\end{array}$ & $\begin{array}{r}-0.0375 \\
(0.026)\end{array}$ & $\begin{array}{c}-0.0375 \\
(0.026)\end{array}$ & $\begin{array}{r}-0.0375 \\
(0.026)\end{array}$ & $\begin{array}{r}-0.0350 \\
(0.027)\end{array}$ & $\begin{array}{r}-0.0347 \\
(0.027)\end{array}$ \\
\hline Urban & $\begin{array}{c}-0.0612 * * * \\
(0.019)\end{array}$ & $\begin{array}{c}-0.0626^{* * *} \\
(0.019)\end{array}$ & $\begin{array}{c}-0.0626^{* * *} \\
(0.019)\end{array}$ & $\begin{array}{c}-0.0611 * * * \\
(0.019)\end{array}$ & $\begin{array}{c}-0.0627^{* * *} \\
(0.018)\end{array}$ & $\begin{array}{c}-0.0627^{* * *} \\
(0.018)\end{array}$ & $\begin{array}{c}-0.0627^{* * *} \\
(0.018)\end{array}$ & $\begin{array}{c}-0.0652^{* * *} \\
(0.019)\end{array}$ & $\begin{array}{c}-0.0645^{* * * *} \\
(0.019)\end{array}$ \\
\hline Education & $\begin{array}{l}-0.0045 \\
(0.005)\end{array}$ & $\begin{array}{l}-0.0043 \\
(0.005)\end{array}$ & $\begin{array}{l}-0.0041 \\
(0.005)\end{array}$ & $\begin{array}{l}-0.0045 \\
(0.005)\end{array}$ & $\begin{array}{c}-0.0050 \\
(0.004)\end{array}$ & $\begin{array}{c}-0.0048 \\
(0.004)\end{array}$ & $\begin{array}{r}-0.0049 \\
(0.004)\end{array}$ & $\begin{array}{c}-0.0032 \\
(0.005)\end{array}$ & $\begin{array}{l}-0.0034 \\
(0.005)\end{array}$ \\
\hline Wealth & $\begin{array}{l}-0.0075 \\
(0.022)\end{array}$ & $\begin{array}{l}-0.0067 \\
(0.022)\end{array}$ & $\begin{array}{l}-0.0068 \\
(0.022)\end{array}$ & $\begin{array}{l}-0.0060 \\
(0.022)\end{array}$ & $\begin{array}{l}-0.0040 \\
(0.021)\end{array}$ & $\begin{array}{l}-0.0042 \\
(0.021)\end{array}$ & $\begin{array}{l}-0.0047 \\
(0.021)\end{array}$ & $\begin{array}{l}-0.0042 \\
(0.021)\end{array}$ & $\begin{array}{l}-0.0069 \\
(0.021)\end{array}$ \\
\hline Employment & $\begin{array}{l}0.0023 \\
(0.017)\end{array}$ & $\begin{array}{l}0.0042 \\
(0.017)\end{array}$ & $\begin{array}{l}0.0058 \\
(0.017)\end{array}$ & $\begin{array}{l}0.0030 \\
(0.017)\end{array}$ & $\begin{array}{c}-0.0014 \\
(0.017)\end{array}$ & $\begin{array}{l}-0.0019 \\
(0.017)\end{array}$ & $\begin{array}{l}-0.0017 \\
(0.017)\end{array}$ & $\begin{array}{c}-0.0021 \\
(0.017)\end{array}$ & $\begin{array}{l}-0.0021 \\
(0.017)\end{array}$ \\
\hline Male & $\begin{array}{l}0.0181 \\
(0.015)\end{array}$ & $\begin{array}{l}0.0178 \\
(0.015)\end{array}$ & $\begin{array}{l}0.0176 \\
(0.015)\end{array}$ & $\begin{array}{l}0.0179 \\
(0.015)\end{array}$ & $\begin{array}{c}0.0297 * * \\
(0.015)\end{array}$ & $\begin{array}{c}0.0296^{* *} \\
(0.015)\end{array}$ & $\begin{array}{c}0.0297 * * \\
(0.015)\end{array}$ & $\begin{array}{c}0.0327 * * \\
(0.015)\end{array}$ & $\begin{array}{c}0.0329^{* *} \\
(0.015)\end{array}$ \\
\hline Difficulty of evading taxes & $\begin{array}{l}-0.0022 \\
(0.010)\end{array}$ & $\begin{array}{c}-0.0032 \\
(0.010)\end{array}$ & $\begin{array}{c}-0.0018 \\
(0.010)\end{array}$ & $\begin{array}{r}-0.0013 \\
(0.010)\end{array}$ & $\begin{array}{l}0.0037 \\
(0.009)\end{array}$ & $\begin{array}{l}0.0036 \\
(0.009)\end{array}$ & $\begin{array}{l}0.0036 \\
(0.009)\end{array}$ & $\begin{array}{l}0.0064 \\
(0.010)\end{array}$ & $\begin{array}{l}0.0068 \\
(0.010)\end{array}$ \\
\hline Handling of health and education services & $\begin{array}{c}0.0748^{* * *} \\
(0.013)\end{array}$ & $\begin{array}{c}0.0741 * * * \\
(0.013)\end{array}$ & $\begin{array}{c}0.0741 * * * \\
(0.013)\end{array}$ & $\begin{array}{c}0.0734 * * * \\
(0.013)\end{array}$ & $\begin{array}{c}0.0759 * * * \\
(0.012)\end{array}$ & $\begin{array}{c}0.0765^{* * *} \\
(0.012)\end{array}$ & $\begin{array}{c}0.0766^{* * * *} \\
(0.012)\end{array}$ & $\begin{array}{c}0.0763^{* * * *} \\
(0.012)\end{array}$ & $\begin{array}{c}0.0760 * * * \\
(0.012)\end{array}$ \\
\hline Infrastructure & $\begin{array}{c}0.0565^{* * *} \\
(0.015)\end{array}$ & $\begin{array}{c}0.0567^{* * *} \\
(0.015)\end{array}$ & $\begin{array}{c}0.0585^{* * *} \\
(0.015)\end{array}$ & $\begin{array}{c}0.0582 * * * \\
(0.015)\end{array}$ & $\begin{array}{c}0.0640^{* * *} \\
(0.014)\end{array}$ & $\begin{array}{c}0.0638^{* * *} \\
(0.014)\end{array}$ & $\begin{array}{c}0.0636^{* * * *} \\
(0.014)\end{array}$ & $\begin{array}{c}0.0677 * * * \\
(0.014)\end{array}$ & $\begin{array}{c}0.0678^{* * *} \\
(0.014)\end{array}$ \\
\hline Reducing crime & $\begin{array}{c}0.0771^{* * *} \\
(0.014)\end{array}$ & $\begin{array}{c}0.0776^{* * *} \\
(0.014)\end{array}$ & $\begin{array}{c}0.0760^{* * *} \\
(0.014)\end{array}$ & $\begin{array}{c}0.0765^{* * *} \\
(0.014)\end{array}$ & $\begin{array}{c}0.0734 * * * \\
(0.013)\end{array}$ & $\begin{array}{c}0.0732 * * * \\
(0.013)\end{array}$ & $\begin{array}{c}0.0730^{* * *} \\
(0.013)\end{array}$ & $\begin{array}{c}0.0739 * * * \\
(0.013)\end{array}$ & $\begin{array}{c}0.0738 * * * \\
(0.013)\end{array}$ \\
\hline Handling of improving living standards & $\begin{array}{c}0.1268^{* * * *} \\
(0.016)\end{array}$ & $\begin{array}{c}0.1271^{* * *} \\
(0.016)\end{array}$ & $\begin{array}{c}0.1269^{* * *} \\
(0.016)\end{array}$ & $\begin{array}{c}0.1272 * * * \\
(0.016)\end{array}$ & $\begin{array}{c}0.1301^{* * *} \\
(0.015)\end{array}$ & $\begin{array}{c}0.1302 * * * \\
(0.015)\end{array}$ & $\begin{array}{c}0.1300^{* * *} \\
(0.015)\end{array}$ & $\begin{array}{c}0.1294 * * * \\
(0.015)\end{array}$ & $\begin{array}{c}0.1289 * * * \\
(0.015)\end{array}$ \\
\hline Unfair treatment of own ethnic group & $\begin{array}{c}-0.0648^{* * *} \\
(0.009)\end{array}$ & $\begin{array}{c}-0.0641 * * * \\
(0.009)\end{array}$ & $\begin{array}{c}-0.0645^{* * *} \\
(0.009)\end{array}$ & $\begin{array}{c}-0.0652 * * * \\
(0.009)\end{array}$ & $\begin{array}{c}-0.0704 * * * \\
(0.009)\end{array}$ & $\begin{array}{c}-0.0703 * * * \\
(0.009)\end{array}$ & $\begin{array}{c}-0.0705^{* * *} \\
(0.009)\end{array}$ & $\begin{array}{c}-0.0739 * * * \\
(0.009)\end{array}$ & $\begin{array}{c}-0.0747 * * * \\
(0.009)\end{array}$ \\
\hline Democracy & $\begin{array}{c}0.1270^{* * *} \\
(0.009)\end{array}$ & $\begin{array}{c}0.1277^{* * *} * \\
(0.009)\end{array}$ & $\begin{array}{c}0.1276^{* * *} \\
(0.009)\end{array}$ & $\begin{array}{c}0.1276^{* * * *} \\
(0.009)\end{array}$ & $\begin{array}{c}0.1327 * * * \\
(0.008)\end{array}$ & $\begin{array}{c}0.1325^{* * * *} \\
(0.008)\end{array}$ & $\begin{array}{c}0.1325^{* * * *} \\
(0.008)\end{array}$ & $\begin{array}{c}0.1308^{* * * *} \\
(0.008)\end{array}$ & $\begin{array}{c}0.1302 * * * \\
(0.008)\end{array}$ \\
\hline Satisfaction with politicians & $\begin{array}{c}0.3412^{* * *} \\
(0.012)\end{array}$ & $\begin{array}{c}0.3395^{* * *} \\
(0.012)\end{array}$ & $\begin{array}{c}0.3405^{* * * *} \\
(0.012)\end{array}$ & $\begin{array}{c}0.3407 * * * \\
(0.012)\end{array}$ & $\begin{array}{c}0.3473^{* * *} \\
(0.012)\end{array}$ & $\begin{array}{c}0.3472 * * * \\
(0.012)\end{array}$ & $\begin{array}{c}0.3474 * * * \\
(0.012)\end{array}$ & $\begin{array}{c}0.3389 * * * \\
(0.012)\end{array}$ & $\begin{array}{c}0.3403 * * * \\
(0.012)\end{array}$ \\
\hline Difficulty of finding which taxes to pay & $\begin{array}{c}-0.0975^{* * *} \\
(0.009)\end{array}$ & $\begin{array}{c}-0.0971^{* * *} \\
(0.009)\end{array}$ & $\begin{array}{c}-0.0980 * * * \\
(0.009)\end{array}$ & $\begin{array}{c}-0.0986^{* * *} \\
(0.009)\end{array}$ & $\begin{array}{c}-0.0985^{* * *} \\
(0.009)\end{array}$ & $\begin{array}{c}-0.0984 * * * \\
(0.009)\end{array}$ & $\begin{array}{c}-0.0982 * * * \\
(0.009)\end{array}$ & $\begin{array}{c}-0.1004 * * * \\
(0.009)\end{array}$ & $\begin{array}{c}-0.1006^{* * *} \\
(0.009)\end{array}$ \\
\hline Media & $\begin{array}{l}0.0043 \\
(0.025)\end{array}$ & $\begin{array}{l}0.0042 \\
(0.025)\end{array}$ & $\begin{array}{l}0.0065 \\
(0.025)\end{array}$ & $\begin{array}{l}0.0062 \\
(0.025)\end{array}$ & $\begin{array}{l}0.0117 \\
(0.024)\end{array}$ & $\begin{array}{l}0.0117 \\
(0.024)\end{array}$ & $\begin{array}{l}0.0113 \\
(0.024)\end{array}$ & $\begin{array}{l}0.0060 \\
(0.024)\end{array}$ & $\begin{array}{l}0.0057 \\
(0.024)\end{array}$ \\
\hline Oil deposits & $\begin{array}{c}-0.2697 * * * \\
(0.095)\end{array}$ & $\begin{array}{c}-0.1787 * \\
(0.097)\end{array}$ & $\begin{array}{c}-0.2346^{* *} \\
(0.099)\end{array}$ & $\begin{array}{c}-0.3041 * * * \\
(0.099)\end{array}$ & $\begin{array}{c}-0.2521 * * * \\
(0.096)\end{array}$ & $\begin{array}{c}-0.2802 * * * \\
(0.095)\end{array}$ & $\begin{array}{c}-0.2809^{* * *} \\
(0.095)\end{array}$ & $\begin{array}{c}-0.3461 * * * \\
(0.101)\end{array}$ & $\begin{array}{c}-0.4161 * * * \\
(0.102)\end{array}$ \\
\hline GDP per capita, log & $\begin{array}{c}0.1089 * * \\
(0.050)\end{array}$ & $\begin{array}{c}0.0809^{* *} \\
(0.041)\end{array}$ & $\begin{array}{l}-0.0485 \\
(0.057)\end{array}$ & $\begin{array}{l}0.0253 \\
(0.034)\end{array}$ & $\begin{array}{r}-0.0260 \\
(0.044)\end{array}$ & $\begin{array}{l}0.0284 \\
(0.031)\end{array}$ & $\begin{array}{l}0.0156 \\
(0.032)\end{array}$ & $\begin{array}{l}0.0356 \\
(0.034)\end{array}$ & $\begin{array}{c}0.1071^{* * *} \\
(0.030)\end{array}$ \\
\hline Observations & 22,248 & 22,248 & 22,248 & 22,248 & 24,182 & 24,182 & 24,182 & 23,438 & 23,438 \\
\hline Number of regions & 301 & 301 & 301 & 301 & 334 & 334 & 334 & 310 & 310 \\
\hline Number of countries & 26 & 26 & 26 & 26 & 26 & 26 & 26 & 26 & 26 \\
\hline Region fixed effects & Yes & Yes & Yes & Yes & Yes & Yes & Yes & Yes & Yes \\
\hline Ethnicity fixed effects & Yes & Yes & Yes & Yes & Yes & Yes & Yes & Yes & Yes \\
\hline Religion fixed effects & Yes & Yes & Yes & Yes & Yes & Yes & Yes & Yes & Yes \\
\hline
\end{tabular}

Standard errors in parentheses. ${ }^{* * *} \mathrm{p}<0.01,{ }^{* *} \mathrm{p}<0.05,{ }^{*} \mathrm{p}<0.1$ 


\section{INTERNET SHUTDOWNS AND GOVERNMENT SUCCESS IN ICT PROMOTION}

\section{A. Internet shutdowns}

In this section, we explore whether government shutdowns of internet can alter the impact of digitalization on corruption. An Internet shutdown is an intentional disruption of internet-based communications, rendering them inaccessible or effectively unavailable, for a specific population, location, or mode of access, often to exert control over the flow of information. Internet shutdowns can happen at a national level, where users across the entire country are unable to access the internet, or at a subnational (local) level, where mobile and/or fixed Internet access in a state, city, or other localized area is cut off. In this paper, we do not make the difference between localized or nationwide shutdowns as available data are not disaggregated.

The intentional use of Internet blackouts as a method of controlling the information landscape can have some economic and human rights impacts and breach the trust of citizens in government actions. In fact, internet shutdowns undermine users' trust in the Internet, the reliability of critical online government services, and raise the perception that the government has something to hide. Internet shutdowns can deprive people of vital information and restrict the citizen's ability to hold government or public officials to account. To investigate whether the blackout of Internet can alter the relationship between digitalization and perception of corruption, we extracted the data on the number of Internet shutdowns from The Internet Society and NetBlocks. ${ }^{2}$ We then interacted the number of Internet shutdowns with our different indicators of digitalization, and estimated equation (1). The results are reported in Tables 9. We find that the coefficient associated with the interactive variables between digitalization and the number of Internet shutdowns are positive and significant in columns (69), Table 9, implying that the dampening effect of digitalization on the perception of corruption of tax officials is dampened in countries with high number of Internet blackouts.

\footnotetext{
${ }^{2}$ Available on https://netblocks.org/projects/cost. Accessed on December 2019.
} 
Table 9: Digitalization, corruption and internet shutdowns

\begin{tabular}{|c|c|c|c|c|c|c|c|c|c|}
\hline \multirow[b]{3}{*}{ VARIABLES } & $(1)$ & (2) & (3) & (4) & (5) & (6) & (7) & (8) & (9) \\
\hline & \multicolumn{4}{|c|}{ Digital Adoption Index (DAI) } & \multirow{2}{*}{$\begin{array}{c}\text { E-Government } \\
\text { Index }\end{array}$} & \multirow{2}{*}{\begin{tabular}{|c|}
$\begin{array}{c}\text { E-Participation } \\
\text { Index }\end{array}$ \\
\end{tabular}} & \multirow{2}{*}{\begin{tabular}{|c} 
Online Service \\
Index
\end{tabular}} & \multirow{2}{*}{ Open budget } & \multirow{2}{*}{ PFM e-services } \\
\hline & Aggregate & DAI Business & DAI People & DAI Government & & & & & \\
\hline Digitalization & $\begin{array}{c}-1.5609 * * * \\
(0.324)\end{array}$ & $\begin{array}{c}-1.6404 * * * \\
(0.274)\end{array}$ & $\begin{array}{c}-1.2204 * * * \\
(0.291)\end{array}$ & $\begin{array}{c}-0.5400^{* *} \\
(0.228)\end{array}$ & $\begin{array}{c}-1.5440^{* * *} \\
(0.301)\end{array}$ & $\begin{array}{c}-1.1015^{* * *} \\
(0.209)\end{array}$ & $\begin{array}{c}-1.4756^{* * *} \\
(0.258)\end{array}$ & $\begin{array}{c}-0.9812^{* * *} \\
(0.167)\end{array}$ & $\begin{array}{c}-1.8193^{* * *} \\
(0.319)\end{array}$ \\
\hline Digitalization*Internet shutdowns & $\begin{array}{r}-0.0837 \\
(0.359)\end{array}$ & $\begin{array}{l}0.1653 \\
(0.324)\end{array}$ & $\begin{array}{c}0.2186^{* *} \\
(0.061)\end{array}$ & $\begin{array}{l}-0.1091 \\
(0.270)\end{array}$ & $\begin{array}{c}0.2833^{* * * *} \\
(0.032)\end{array}$ & $\begin{array}{c}0.3211^{* *} \\
(0.139)\end{array}$ & $\begin{array}{c}0.4848 * * * \\
(0.167)\end{array}$ & $\begin{array}{c}0.0047^{*} \\
(0.003)\end{array}$ & $\begin{array}{c}0.0116^{* * *} \\
(0.003)\end{array}$ \\
\hline Internet shutdowns & $\begin{array}{l}0.0955 \\
(0.135)\end{array}$ & $\begin{array}{l}0.1434 \\
(0.139)\end{array}$ & $\begin{array}{l}0.1533^{*} \\
(0.087)\end{array}$ & $\begin{array}{l}0.0864 \\
(0.119)\end{array}$ & $\begin{array}{l}-0.0190 \\
(0.108)\end{array}$ & $\begin{array}{l}-0.0369 \\
(0.047)\end{array}$ & $\begin{array}{l}-0.0619 \\
(0.047)\end{array}$ & $\begin{array}{l}-0.1157 \\
(0.130)\end{array}$ & $\begin{array}{c}-0.5331^{* * *} \\
(0.196)\end{array}$ \\
\hline Observations & 21,758 & 21,758 & 21,758 & 21,758 & 23,644 & 23,644 & 23,644 & 22,899 & 22,899 \\
\hline Number of regions & 296 & 296 & 296 & 296 & 329 & 329 & 329 & 305 & 305 \\
\hline Number of countries & 26 & 27 & 28 & 29 & 30 & 31 & 32 & 32 & 32 \\
\hline Control variables & Yes & Yes & Yes & Yes & Yes & Yes & Yes & Yes & Yes \\
\hline Region fixed effects & Yes & Yes & Yes & Yes & Yes & Yes & Yes & Yes & Yes \\
\hline Ethnicity fixed effects & Yes & Yes & Yes & Yes & Yes & Yes & Yes & Yes & Yes \\
\hline Religion fixed effects & Yes & Yes & Yes & Yes & Yes & Yes & Yes & Yes & Yes \\
\hline
\end{tabular}

\section{B. Government success in promoting ICT}

A successful implementation of ICTs has proven to be an effective instrument for connecting not only citizens and public officials but also disparate government communication networks at every level. To achieve this, several countries have implemented some initiatives to significantly increase the participation of citizens in public decision-making and providing citizens with a central window to government services, while other countries have conducted some policies aiming at making ICT tools accessible to the public. To explore whether a successful promotion of ICT tools matters, we create an interactive variable between our different indicators of digitalization and the index of government success in promoting ICT, which is extracted from the World Economic Forum. This index is constructed based on survey responses from all countries. In these surveys, respondents are asked: "In your country, how successful is the government in promoting the use of ICTs? $(1=$ not successful at all; $7=$ extremely successful)". The results reported in Table 10 show that the coefficients associated with the interactive variable between digitalization and the index of government success in promoting ICT are negative and strongly significant in columns 1-4. Therefore, a successful promotion of ICT could amplify the dampening effect of digitalization on the level of corruption perception of tax officials. 
Table 10: Digitalization, corruption and ICT promotion

\begin{tabular}{|c|c|c|c|c|c|c|c|c|c|}
\hline \multirow[b]{3}{*}{ VARIABLES } & (1) & (2) & (3) & (4) & \multirow{3}{*}{\begin{tabular}{|c|} 
(5) \\
E-Government \\
Index \\
\end{tabular}} & \multirow{3}{*}{\begin{tabular}{|c|} 
(6) \\
E-Participation \\
Index \\
\end{tabular}} & \multirow{3}{*}{$\begin{array}{c}(7) \\
\text { Online Service } \\
\text { Index }\end{array}$} & \multirow{3}{*}{ Open budget } & \multirow{3}{*}{$\begin{array}{c}\text { (9) } \\
\text { PFM e- } \\
\text { services } \\
\end{array}$} \\
\hline & \multicolumn{4}{|c|}{ Digital Adoption Index (DAI) } & & & & & \\
\hline & Aggregate & DAI Business & DAI People & DAI Government & & & & & \\
\hline Digitalization & $\begin{array}{c}-4.3558^{* * *} \\
(0.655)\end{array}$ & $\begin{array}{c}-2.6775^{* * *} \\
(0.691)\end{array}$ & $\begin{array}{c}-3.5132 * * * \\
(0.603)\end{array}$ & $\begin{array}{c}-2.9100 * * * \\
(0.499)\end{array}$ & $\begin{array}{c}-1.9384 * * * \\
(0.520)\end{array}$ & $\begin{array}{c}-0.8116^{* * *} \\
(0.304)\end{array}$ & $\begin{array}{c}-1.2869 * * * \\
(0.409)\end{array}$ & $\begin{array}{c}-0.4052 * * \\
(0.466)\end{array}$ & $\begin{array}{c}-0.1179^{* *} \\
(0.021)\end{array}$ \\
\hline Digitalization*government success & $\begin{array}{c}-1.9468 * * * \\
(0.468)\end{array}$ & $\begin{array}{c}-1.6993 * * * \\
(0.529)\end{array}$ & $\begin{array}{c}-1.4479 * * * \\
(0.511)\end{array}$ & $\begin{array}{c}-1.0741^{* * * *} \\
(0.292)\end{array}$ & $\begin{array}{l}-0.3032 \\
(0.370)\end{array}$ & $\begin{array}{l}-0.0955 \\
(0.276)\end{array}$ & $\begin{array}{l}-0.2729 \\
(0.324)\end{array}$ & $\begin{array}{l}-1.2261 \\
(1.205)\end{array}$ & $\begin{array}{l}-0.9076 \\
(1.691)\end{array}$ \\
\hline Government success & $\begin{array}{c}-1.7782 * * * \\
(0.403)\end{array}$ & $\begin{array}{c}-1.5462 * * * \\
(0.504)\end{array}$ & $\begin{array}{c}-1.4017^{* * *} \\
(0.461)\end{array}$ & $\begin{array}{c}-0.7587^{* * * *} \\
(0.219)\end{array}$ & $\begin{array}{l}-0.2550 \\
(0.341)\end{array}$ & $\begin{array}{l}-0.0797 \\
(0.263)\end{array}$ & $\begin{array}{l}-0.2473 \\
(0.267)\end{array}$ & $\begin{array}{r}-0.2849 \\
(0.377)\end{array}$ & $\begin{array}{l}-0.5147 \\
(1.031)\end{array}$ \\
\hline Observations & 19,909 & 19,909 & 19,909 & 19,909 & 21,481 & 21,481 & 21,481 & 20,736 & 20,736 \\
\hline Number of regions & 284 & 284 & 284 & 284 & 315 & 315 & 315 & 291 & 291 \\
\hline Number of countries & 25 & 26 & 27 & 28 & 29 & 30 & 31 & 31 & 31 \\
\hline Control variables & Yes & Yes & Yes & Yes & Yes & Yes & Yes & Yes & Yes \\
\hline Region fixed effects & Yes & Yes & Yes & Yes & Yes & Yes & Yes & Yes & Yes \\
\hline Ethnicity fixed effects & Yes & Yes & Yes & Yes & Yes & Yes & Yes & Yes & Yes \\
\hline Religion fixed effects & Yes & Yes & Yes & Yes & Yes & Yes & Yes & Yes & Yes \\
\hline
\end{tabular}

\section{THE ARRIVAL OF FAST INTERNET: IDENTIFYING THE CAUSAL EFFECT OF DIGITALIZATION ON CORRUPTION}

Submarine cables are the world's primary path for international communications, international e-commerce, and digitally enabled services. Without submarine cable systems, global telecommunications, including the internet, with its sophistication, speed and resilience, would be limited. In these recent years, African countries have experienced a strong increase in the deployment of submarine Internet cables (Cariolle, 2019). Once plugged in, submarine cables brought much faster speed and traffic capacities on Internet traffic to and from other continents to locations in Africa connected to the terrestrial network (Hjort and Poulsen, 2019). As Cariolle (2019) and IMF (2020) found, the arrival of submarine cables is not linked to the level of development of countries but has led to an increase of internet penetration rates by 3-4 percentage points.

Following Hjort and Poulsen (2019), we use the exogeneous variations in the deployment of submarine cables to identify the causal effect of digitalization on the perception of corruption of tax officials. Basically, we compare individuals in locations in Africa that are on the terrestrial network of Internet cables to those that are not. The dependent variable is the use of internet at the individual level obtained from the Afrobarometer survey. To this end, we refer 
to question Q92B which asks: “How often do you use: The Internet?”. Possible responses are: "Never"; "less than once a month"; "a few times a month"; "a few times a week" and "every day". We code these responses as following: 0 if the response is "Never"; 1 if the response is "less than once a month"; 2 if it is "a few times a month"; 3 if the response is "a few times a week", and 4 if the answer is "every day". As for the data on the submarine cables, we rely on the subnational (district, province or county depending on each country administrative division) data from Hjort and Poulsen (2019), which are originally from Akamai (2012). This variable takes the value of 1 if a district/region is connected to a submarine Internet cable and 0 otherwise.

To estimate the causal effect of the use of internet on the perception of corruption, we employ an instrument variable approach-the two-stage least-square method. The exogeneous variations in the connection to a submarine cable are used as instrument for the use of internet. The exogeneity of the connection to a submarine cable is a reasonable assumption. Still, some may argue that richer countries are more likely to be connected to a submarine cable as they have more financial resources. This potential effect is already accounted in our estimates as we control for the level of development of countries. The results are reported in Table 11. All the statistical tests about the strength of the instrument are in line with expectations. At the first stage, the coefficient associated with submarine cables is positive and strongly significant, suggesting that the deployment of submarine cables is a good predictor of the use of Internet in Africa. In addition, the Hansen and Anderson-Rubin Wald tests show that the instrument is exogeneous and not weak. Moreover, as expected, we find that the coefficient associated with the use of internet is negative and strongly significant at the 1 percent level (see column 1), confirming our baseline findings in Table 1. 
Table 11. Submarine cables: identifying the causal effect

\begin{tabular}{lcc}
\hline VARIABLES & $(1)$ & $(2)$ \\
\cline { 2 - 3 } & OLS & IV \\
\hline Use of Internet & $-0.0131^{* *}$ & $-0.4092^{* * *}$ \\
& $(0.006)$ & $(0.101)$ \\
Observations & & \\
Number of countries & 23,635 & 23,640 \\
R-squared & 27 & 27 \\
Hansen p-value & 0.109 & 0.135 \\
Cragg-Donald Wald F statistic & & 0.52 \\
Anderson-Rubin Wald test, $\mathrm{p}-\mathrm{value}$ & & 36.75 \\
Control variables & & 0.00 \\
Region fixed effects & Yes & Yes \\
Ethnicity fixed effects & Yes & Yes \\
Religion fixed effects & Yes & Yes \\
Standard errors in parentheses. $* * * \mathrm{p}<0.01, * * \mathrm{p}<0.05, *$ & $\mathrm{p}<0.1$
\end{tabular}

\section{Conclusion}

This paper empirically studies the relationship between digitalization and the perception of corruption and trust in tax officials. It underscores that the adoption of digital tools would be crucial in the fight against corruption

First, using survey data from more than 23,000 individuals in 26 African countries, (Sixth Afrobarometer round) and several indicators of digitalization, we find that the adoption of digital tools is associated with a lower perception of corruption and a higher trust in tax officials. On average, the adoption of digital tools is correlated with a reduction of corruption perception in the tax administration by around 3 percentage points. The results are robust to the use of different indicators of digitalization, including the World Bank's Digital Adoption Index and its components, the UN's e-Government, e-Participation and Online services indices and the World Bank's open budget et Public Financial Management (PFM) e-services indices.

Second, our results suggest that the potential dampening effect of digitalization on the perception of corruption is due to its effect on trust in tax officials. By bringing transparency 
and reducing the opportunities for bribes and influence, digitalization can improve trust in government officials, which is a key element in the citizens' perceived level of corruption.

Third, the paper finds that increased Internet usage leads to lower perception of corruption. It identifies the causal effect of the use of internet on the perception of corruption using the exogeneous variations in the deployment of submarine cables at the subnational level.

Fourth, the paper finds that Internet shutdowns by governments undermine the trust of citizens in the Internet and in government actions and raise the perception that the government is corrupt. In contrast, our results indicate that government policies to promote ICT strengthen the impact of digitalization in reducing the perception of corruption. The paper underscores that African countries should step up the adoption of digital tools to combat corruption and they should refrain from intentionally shutting down the Internet.

Going forward, more work is needed to understand the payoffs of different investments to spur digitalization on African economies starting from the provision of basic infrastructure such as electricity to the availability of affordable and reliable internet services and the design of relevant applications and services. For instance, a longstanding challenge in many sub-Saharan African countries is the efficient collection of taxes and delivery of public services and social spending. If well implemented, there are potential gains in tax administration and compliance, targeting of social programs, and public financial management, more broadly using existing data on transactions and combining it with personal information. Public procurement could also benefit from the use of smart contracts that are designed to facilitate, verify, or enforce contract negotiations or performance. Moreover, the use of distributed ledger technology (DLT) could offer tools to help promote transparency and reduce corruption. 


\section{REFERENCES}

African Union Commission. 2019. Domestic Resource Mobilization: Fighting against Corruption and Illicit Financial Flows. AUC Publishing, Addis Ababa.

Akamai. 2012. The State of the Internet: 4th quarter, 2012 Report https://www.slideshare.net/ AkamaiTechnologies/q4-2012-sotiweb.

Ali, M., Fjeldstad, O. and Sjursen, I. H. 2014. To pay or not to pay? Citizens' attitudes toward taxation in Kenya, Tanzania, Uganda, and South Africa. World Development 64: 828-842.

Ali, M., Fjeldstad, O., and Sjursen, I. H., 2014. To Pay or Not to Pay? Citizens' Attitudes Toward Taxation in Kenya, Tanzania, Uganda, and South Africa. World Development 64: 828-842.

Bellon, M., Chang, J., Dabla-Norris, E., Khalid, S., Lima, F., Rojas, E. and Villena, P. 2019. Digitalization to Improve Tax Compliance: Evidence from VAT e-Invoicing in Peru. IMF WP 19/231. Washington, DC

Brehm, J. and Rahn, W. 1997. Individual Level Evidence for the Causes and Consequences of Social Capital. American Journal of Political Science 41:888-1023.

Bryk, A. S., and Raudenbush, S. W. 1992. Hierarchical linear models: Applications and data analysis methods. Newbury Park, London, New Dehli: Sage Publications.

Cariolle, J. 2019. Telecommunication Submarine-cable Deployment and the Digital Divide in Sub-Saharan Africa. FERDI Working Paper Series 241, Clermont-Ferrand, France.

D’Agostino, G., Dunne, J. P. and Pieroni, L. 2016. Government Spending, Corruption and Economic Growth. World Development 84: 190-205.

Deloitte. 2016. The Economic Impact of Disruptions to Internet Connectivity. A report for Facebook. London, United Kingdom.

Fan, H., Liu, Y., Qian, N. and Wen, J. 2018. The Dynamic Effects of Computerized VAT Invoices on Chinese Manufacturing Firms. NBER Working Paper No. 24414.

Fisman, R. and Svensson, J. 2007. Are Corruption and Taxation Really Harmful to Growth? Firm Level Evidence. Journal of Development Economics 83(1): 63-75

Gupta, S., M. Keen, A. Shah, and G. Verdier, 2017. Digital Revolutions in Public Finance. Washington, DC: International Monetary Fund.

Hammadi, A., Mills, M., Sobrinho, N., Thakoor, V., and Velloso, R. 2019. A Governance Dividend for Sub-Saharan Africa. IMF Working Paper Series WP/19/1. Washington DC: International Monetary Fund. 
Hjort, J. and Poulsen, J. 2019. The Arrival of Fast Internet and Employment in Africa. American Economic Review 109(3): 1032-1079.

Hudson, J. 2006. Institution Trust and Subjective Well-Being Across the EU. Kyklos, 59(1): 43-62

Hung, M. P. 2001. Corruption and Economic Growth. Journal of Comparative Economics 29(1): 66-79.

International Monetary Fund (IMF). 2018. Capitalizing on Good Times. IMF Fiscal Monitor, April 2018. Washington, DC.

International Monetary Fund (IMF). 2019a. Curbing Corruption. IMF Fiscal Monitor, April 2019. Washington, DC.

International Monetary Fund (IMF). 2019b. Fiscal Policy and Development: Human, Social, and Physical Investment for the SDGs. IMF Staff Discussion Note SDN/19/03. Washington, DC.

International Monetary Fund (IMF). 2019c. FinTech in Sub-Saharan African Countries: A Game Changer? IMF Departmental Papers/Policy Papers 19/04. Washington, DC.

International Monetary Fund (IMF). 2020. Digitalization in Sub-Saharan Africa. Regional Economic Outlook (forthcoming). Washington, DC.

Isaksson, A. and Kotsadam, A., 2018. Racing to the bottom? Chinese development projects and trade union involvement in Africa. World Development 106: 284-298.

Justesen, M. K., and Bjornskov, C., 2014. Exploiting the Poor: Bureaucratic Corruption and Poverty in Africa. World Development 58: 106-115.

Khemani, S., 2015. Buying votes versus supplying public services: Political incentives to under-invest in pro-poor policies. Journal of Development Economics 117: 84-93.

Kinda, T. 2019. E-commerce as a Potential New Engine for Growth in Asia. IMF Working Paper WP 19/135. Washington, DC.

Kolstad, I. and Soreide, T. 2009. Corruption in Natural Resource Management: Implications for Policy Makers. Resources Policy 34(4): 214-226.

Konte, M., 2016. The effects of remittances on support for democracy in Africa: Are remittances a curse or a blessing? Journal of Comparative Economics 44(4): $1002-1022$

Levi, M. 1998. A State of Trust. In Margaret Levi and Valerie Braithwaite, eds., Trust and Governance. New York: Russell Sage Foundation. 
Lewbel, A. 2012. Using Heteroscedasticity to Identify and Estimate Mismeasured and Endogenous Regressor Models. Journal of Business \& Economic Statistics 30(1): 67-80.

Luke, D. A. 2004. Multilevel modelling. Sage University paper series on quantitative applications in the social sciences, 07-143. Thousand Oaks, CA: Sage.

McKerchar, M. and Evans, C. 2009. Sustaining growth in developing economies through improved taxpayer compliance: Challenges for policy makers and revenue authorities. eJournal of Tax Research 7: 171-201.

Mishler, W. and Rose, R. 2005. What are the Political Consequences of Trust? : A Test of Cultural and Institutional Theories in Russia. Comparative Political Studies 38(9): 1050-1078.

Moerbeek, M. 2004. The consequence of ignoring a level of nesting in multilevel analysis. Multivariate Behavioral Research 39: 129-149.

Montalvo, J. G. and Reynal-Querol, M. 2005. Ethnic polarization, potential conflict and civil war. The American Economic Review 95(3): 796-816.

Moore, M. 2004. Revenues, state formation, and the quality of governance in developing countries. International Political Science Review 25: 297-319.

Organisation for Economic Co-operation and Development (OECD). 2018. Trust and Its Determinants: Evidence From The Trustlab Experiment. Working Paper No.89.: Paris, France.

Teltscher, S. Electronic Commerce and Development: Fiscal Implications of Digitalized Goods Trading. World Development 30(7): 1137-1158.

Tranmer, M., and Steel, D. G. 2001. Ignoring a level in a multilevel model: Evidence from UK census data. Environment and Planning A, 33: 941-948.

United States Geological Survey (USGS). 2014. Mineral Facilities of Africa and the Middle East. National Minerals Information Center.

Van den Noortgate, W., Opdenakker, M. C., and Onghena, P. 2005. The effects of ignoring a level in multilevel analysis. School effectiveness and school improvement. An International Journal of Research, Policy and Practice 16: 281-303.

West, D. M. 2016. Internet shutdowns cost countries \$2.4 billion last year. Washington DC: Brookings Institution.

World Bank, 2016. World Development Report 2016: Digital Dividends. World Bank: Washington DC. 
Yılmaz, F., and Coolidge, J. 2013. Can e-filing reduce tax compliance costs in developing countries? World Bank Policy Research Working Paper No. 6647. 


\section{Appendices}

Appendix A 1: Descriptive Statistics

\begin{tabular}{|c|c|c|c|c|c|}
\hline Variable & Obs & Mean & Std. Dev. & Min & Max \\
\hline Corruption of tax officials & 23,635 & 1.5 & 0.9 & 0.0 & 3.0 \\
\hline Trust in tax officials & 23,635 & 1.5 & 1.1 & 0.0 & 3.0 \\
\hline Aggregate DAI & 23,635 & 0.3 & 0.1 & 0.2 & 0.6 \\
\hline DAI Business & 23,635 & 0.4 & 0.1 & 0.2 & 0.7 \\
\hline DAI People & 23,635 & 0.2 & 0.1 & 0.0 & 0.5 \\
\hline DAI Government & 23,635 & 0.4 & 0.1 & 0.2 & 0.8 \\
\hline E-government index & 23,635 & 0.3 & 0.1 & 0.1 & 0.5 \\
\hline E-participation index & 23,635 & 0.3 & 0.2 & 0.0 & 0.8 \\
\hline Online service index & 23,635 & 0.2 & 0.2 & 0.0 & 0.7 \\
\hline Open budget & 23,635 & 0.4 & 0.2 & 0.0 & 0.7 \\
\hline PFM e-services & 23,635 & 0.6 & 0.1 & 0.3 & 0.7 \\
\hline Age, $<25$ & 23,635 & 0.2 & 0.4 & 0.0 & 1.0 \\
\hline Age, $>25$ & 23,635 & 0.7 & 0.5 & 0.0 & 1.0 \\
\hline Urban & 23,635 & 0.4 & 0.5 & 0.0 & 1.0 \\
\hline Education & 23,635 & 3.5 & 2.2 & 0.0 & 9.0 \\
\hline Wealth & 23,635 & 0.2 & 0.4 & 0.0 & 1.0 \\
\hline Employment & 23,635 & 0.4 & 0.5 & 0.0 & 1.0 \\
\hline Male & 23,635 & 0.5 & 0.5 & 0.0 & 1.0 \\
\hline Difficulty of evading taxes & 23,635 & 2.2 & 0.8 & 0.0 & 3.0 \\
\hline Handling of health and education services & 23,635 & 1.4 & 0.8 & 0.0 & 3.0 \\
\hline Infrastructure & 23,635 & 1.3 & 0.8 & 0.0 & 3.0 \\
\hline Reducing crime & 23,635 & 1.2 & 0.8 & 0.0 & 3.0 \\
\hline Handling of improving living standards & 23,635 & 1.0 & 0.8 & 0.0 & 3.0 \\
\hline Unfair treatment of own ethnic group & 23,635 & 0.6 & 0.9 & 0.0 & 3.0 \\
\hline Democracy & 23,635 & 2.4 & 1.0 & 0.0 & 4.0 \\
\hline Satisfaction with politicians & 23,635 & 1.5 & 0.8 & 0.0 & 3.0 \\
\hline Difficulty of finding which taxes to pay & 23,635 & 1.9 & 0.9 & 0.0 & 3.0 \\
\hline Media & 23,635 & 0.3 & 0.4 & 0.0 & 1.0 \\
\hline Oil deposits & 23,635 & 0.0 & 0.2 & 0.0 & 1.0 \\
\hline GDP per capita, log & 23,635 & 8.1 & 0.9 & 6.7 & 9.8 \\
\hline GDP growth & 23,635 & 4.6 & 2.0 & 0.6 & 8.8 \\
\hline Inflation & 23,635 & 7.0 & 5.3 & 0.4 & 28.0 \\
\hline Civil war & 23,635 & 0.4 & 0.3 & 0.0 & 1.0 \\
\hline Poverty & 23,635 & 0.5 & 0.8 & 0.0 & 2.5 \\
\hline
\end{tabular}


Table 2: Robustness: use of digital payments

\begin{tabular}{lcccc}
\hline & \multicolumn{2}{c}{$(1)$} & $(3)$ & $(4)$ \\
\cline { 2 - 5 } VARIABLES & $\begin{array}{c}\text { Made or received } \\
\text { digital payments } \\
(\% \text { age } 15+)\end{array}$ & $\begin{array}{c}\text { Made digital payments } \\
(\% \text { age } 15+)\end{array}$ & $\begin{array}{c}\text { Received digital } \\
\text { payments }(\% \text { age } 15+)\end{array}$ & $\begin{array}{c}\text { Received digital } \\
\text { payments, in labor } \\
\text { force }(\% \text { age } 15+)\end{array}$ \\
\hline Digitalization & $-0.5143^{* * *}$ & $-0.6042^{* * *}$ & $-0.4371^{* *}$ & $-0.8166^{* * *}$ \\
Observations & $(0.175)$ & $(0.155)$ & $(0.186)$ & $(0.180)$ \\
Number of regions & 23,321 & 23,321 & 23,321 & 23,321 \\
Number of countries & 323 & 323 & 323 & 323 \\
Region fixed effects & 26 & 26 & 26 & 26 \\
Ethnicity fixed effects & Yes & Yes & Yes & Yes \\
Religion fixed effects & Yes & Yes & Yes & Yes \\
\hline Stix. & Yes & & Yes \\
\hline
\end{tabular}

Standard errors in parentheses. ${ }^{* * *} \mathrm{p}<0.01,{ }^{* *} \mathrm{p}<0.05,{ }^{*} \mathrm{p}<0.1$ 
Table 3: Robustness: use of mobile money

\begin{tabular}{|c|c|c|c|c|c|c|c|c|c|c|}
\hline & $(1)$ & $(2)$ & $(3)$ & $(4)$ & $(5)$ & (6) & $(7)$ & $(8)$ & (9) & $(10)$ \\
\hline VARIABLES & $\begin{array}{l}\text { Paid utility } \\
\text { bills: using a } \\
\text { mobile phone } \\
(\% \text { age } 15+\text { ) }\end{array}$ & $\begin{array}{l}\text { Paid utility bills: } \\
\text { using a mobile } \\
\text { phone ( } \% \\
\text { paying utility } \\
\text { bills, age } 15+\text { ) }\end{array}$ & $\begin{array}{l}\text { Received } \\
\text { wages: through } \\
\text { a mobile phone } \\
(\% \text { age } 15+)\end{array}$ & $\begin{array}{l}\text { Received private } \\
\text { sector wages: } \\
\text { through a mobile } \\
\text { phone ( } \% \text { age } \\
15+\text { ) }\end{array}$ & $\begin{array}{l}\text { Received public } \\
\text { sector wages: } \\
\text { through a } \\
\text { mobile phone } \\
(\% \text { age } 15+)\end{array}$ & $\begin{array}{l}\text { Paid school } \\
\text { fees: using a } \\
\text { mobile phone } \\
(\% \text { age } 15+)\end{array}$ & $\begin{array}{l}\text { Received payments } \\
\text { for agricultural } \\
\text { products: through a } \\
\text { mobile phone ( } \% \text { age } \\
15+)\end{array}$ & $\begin{array}{l}\text { Received } \\
\text { payments from self- } \\
\text { employment: } \\
\text { through a mobile } \\
\text { phone ( } \% \text { age } 15+\text { ) }\end{array}$ & $\begin{array}{l}\text { Received } \\
\text { government } \\
\text { payments: through } \\
\text { a mobile phone }(\% \\
\text { age } 15+)\end{array}$ & $\begin{array}{l}\text { Mobile } \\
\text { money } \\
\text { account }(\% \\
\text { age } 15+)\end{array}$ \\
\hline Digitalization & $\begin{array}{l}-0.6597 \\
(0.512)\end{array}$ & $\begin{array}{l}-0.0859 \\
(0.153)\end{array}$ & $\begin{array}{l}-2.0542 \\
(1.401)\end{array}$ & $\begin{array}{l}-1.3597 \\
(1.560)\end{array}$ & $\begin{array}{l}0.2589 \\
(1.225)\end{array}$ & $\begin{array}{l}-0.8592 \\
(0.815)\end{array}$ & $\begin{array}{c}-8.4596^{* * *} \\
(1.565)\end{array}$ & $\begin{array}{l}-2.0726 \\
(1.972)\end{array}$ & $\begin{array}{l}0.0748 \\
(0.196)\end{array}$ & $\begin{array}{l}-0.0420 \\
(0.176)\end{array}$ \\
\hline Observations & 23,321 & 23,321 & 23,321 & 22,066 & 19,924 & 22,254 & 13,215 & 15,373 & 22,948 & 22,948 \\
\hline Number of regions & 323 & 323 & 323 & 312 & 266 & 297 & 161 & 174 & 315 & 315 \\
\hline Number of countries & 26 & 26 & 26 & 26 & 23 & 26 & 18 & 19 & 26 & 26 \\
\hline Control variables & Yes & Yes & Yes & Yes & Yes & Yes & Yes & Yes & Yes & Yes \\
\hline Region fixed effects & Yes & Yes & Yes & Yes & Yes & Yes & Yes & Yes & Yes & Yes \\
\hline Ethnicity fixed effects & Yes & Yes & Yes & Yes & Yes & Yes & Yes & Yes & Yes & Yes \\
\hline Religion fixed effects & Yes & Yes & Yes & Yes & Yes & Yes & Yes & Yes & Yes & Yes \\
\hline
\end{tabular}




\section{Table 4: Robustness: use of internet}

\begin{tabular}{|c|c|c|c|c|}
\hline & (1) & (2) & (3) & (4) \\
\hline VARIABLES & $\begin{array}{l}\text { Used the internet } \\
\text { to pay bills ( } \% \\
\text { age } 15+\text { ) }\end{array}$ & $\begin{array}{l}\text { Used the internet to } \\
\text { pay bills, older } \\
\text { adults ( } \% \text { age } 25+\text { ) }\end{array}$ & $\begin{array}{l}\text { Used the internet to pay } \\
\text { bills or to buy something } \\
\text { online (\% age } 15+\end{array}$ & $\begin{array}{c}\text { Used the internet to pay } \\
\text { bills or to buy something } \\
\text { online, older adults (\% } \\
\text { age } 25+\text { ) }\end{array}$ \\
\hline Digitalization & $\begin{array}{c}-1.7104 * * * \\
(0.599)\end{array}$ & $\begin{array}{c}-1.8411 * * * \\
(0.590)\end{array}$ & $\begin{array}{c}-4.4076 * * * \\
(1.570)\end{array}$ & $\begin{array}{c}-3.9614 * * * \\
(1.525)\end{array}$ \\
\hline Observations & 23,321 & 23,321 & 21,775 & 21,775 \\
\hline Number of regions & 323 & 323 & 282 & 282 \\
\hline Number of countries & 26 & 26 & 26 & 26 \\
\hline Control variables & Yes & Yes & Yes & Yes \\
\hline Region fixed effects & Yes & Yes & Yes & Yes \\
\hline Ethnicity fixed effects & Yes & Yes & Yes & Yes \\
\hline Religion fixed effects & Yes & Yes & Yes & Yes \\
\hline
\end{tabular}

Table 5: Robustness: use of internet or mobile phone

\begin{tabular}{lcc}
\hline & $(1)$ & $(2)$ \\
\cline { 2 - 3 } & $\begin{array}{c}\text { Used a mobile phone or } \\
\text { the internet to access a } \\
\text { financial institution } \\
\text { account }(\% \text { age } 15+)\end{array}$ & $\begin{array}{c}\text { Used a mobile phone } \\
\text { or the internet to check } \\
\text { account balance }(\% \\
\text { age } 15+)\end{array}$ \\
\hline & $-1.1293^{* * *}$ & \\
Digitalization & $(0.326)$ & $-1.1321^{* * *}$ \\
& & $(0.262)$ \\
Observations & 21,645 & 21,645 \\
Number of regions & 294 & 294 \\
Number of countries & 26 & 26 \\
Control variables & Yes & Yes \\
Region fixed effects & Yes & Yes \\
Ethnicity fixed effects & Yes & Yes \\
Religion fixed effects & Yes & Yes \\
\hline Standard errors in parentheses. $* * * \mathrm{p}<0.01, * * \mathrm{p}<0.05, * \mathrm{p}<0.1$ &
\end{tabular}


Table 6: Robustness: using alternative econometric method: Lewbel (2012)

\begin{tabular}{|c|c|c|c|c|c|c|c|c|c|}
\hline \multirow[b]{3}{*}{ VARIABLES } & $(1)$ & $(2)$ & (3) & $(4)$ & \multirow{3}{*}{\begin{tabular}{|c|c|} 
E-Government \\
Index \\
\end{tabular}} & \multirow{3}{*}{\begin{tabular}{|c} 
(6) \\
E-Participation \\
Index \\
\end{tabular}} & \multirow{3}{*}{\begin{tabular}{|c|}
$(7)$ \\
Online \\
Service Index
\end{tabular}} & \multirow{3}{*}{$\frac{(8)}{\text { Open budget }}$} & \multirow{3}{*}{$\begin{array}{c}\text { (9) } \\
\text { PFM e- } \\
\text { services }\end{array}$} \\
\hline & \multicolumn{4}{|c|}{\begin{tabular}{c|} 
Digital Adoption Index (DAI) \\
\end{tabular}} & & & & & \\
\hline & Aggregate DAI & DAI Business & DAI People & DAI Government & & & & & \\
\hline Digitalization & $\begin{array}{c}-1.3474 * * * \\
(0.059)\end{array}$ & $\begin{array}{c}-1.2452^{* * *} \\
(0.051)\end{array}$ & $\begin{array}{c}-1.0100^{* * *} \\
(0.052)\end{array}$ & $\begin{array}{c}-0.5618 * * * \\
(0.043)\end{array}$ & $\begin{array}{c}-1.0395 * * * \\
(0.055)\end{array}$ & $\begin{array}{c}-0.4748 * * * * \\
(0.033)\end{array}$ & $\begin{array}{c}-0.7382^{* * *} \\
(0.042)\end{array}$ & $\begin{array}{c}-0.5252^{* * *} \\
(0.030)\end{array}$ & $\begin{array}{c}-0.6826^{* * * *} \\
(0.055)\end{array}$ \\
\hline Observations & 21,866 & 21,866 & 21,866 & 21,866 & 23,752 & 23,752 & 23,752 & 23,007 & 23,007 \\
\hline R-squared & 0.129 & 0.132 & 0.124 & 0.116 & 0.120 & 0.115 & 0.118 & 0.119 & 0.113 \\
\hline Number of countries & 26 & 26 & 26 & 26 & 26 & 26 & 26 & 26 & 26 \\
\hline Control variables & Yes & Yes & Yes & Yes & Yes & Yes & Yes & Yes & Yes \\
\hline Region fixed effects & Yes & Yes & Yes & Yes & Yes & Yes & Yes & Yes & Yes \\
\hline Ethnicity fixed effects & Yes & Yes & Yes & Yes & Yes & Yes & Yes & Yes & Yes \\
\hline Religion fixed effects & Yes & Yes & Yes & Yes & Yes & Yes & Yes & Yes & Yes \\
\hline
\end{tabular}

Robust standard errors in parentheses. ${ }^{* * *} \mathrm{p}<0.01,{ }^{* *} \mathrm{p}<0.05,{ }^{*} \mathrm{p}<0.1$

Table 7: Robustness: including additional macro variables

\begin{tabular}{|c|c|c|c|c|c|c|c|c|c|}
\hline \multirow[b]{3}{*}{ VARIABLES } & (1) & (2) & (3) & (4) & \multirow{3}{*}{\begin{tabular}{|c|} 
E-Government \\
Index
\end{tabular}} & \multirow{3}{*}{\begin{tabular}{|c|} 
E-Participation \\
Index \\
\end{tabular}} & \multirow{3}{*}{\begin{tabular}{|c|}
$(7)$ \\
Online \\
Service Index
\end{tabular}} & \multirow{3}{*}{\begin{tabular}{|c|}
$(8)$ \\
Open budget
\end{tabular}} & \multirow{3}{*}{$\begin{array}{c}\text { (9) } \\
\text { PFM e- } \\
\text { services }\end{array}$} \\
\hline & \multicolumn{4}{|c|}{ Digital Adoption Index (DAI) } & & & & & \\
\hline & Aggregate DAI & DAI Business & DAI People & DAI Government & & & & & \\
\hline Digitalization & $-1.1174 * *$ & $\begin{array}{c}-2.0942 * * * \\
(0.472)\end{array}$ & $\begin{array}{c}-0.4181^{* * *} \\
(0.083)\end{array}$ & $\begin{array}{c}-0.5009^{*} \\
(0265)\end{array}$ & -0.2541 & $-0.5210^{* * *}$ & $-0.5405^{* *}$ & $-0.6097 * * *$ & $-1.5984 * * *$ \\
\hline \multirow[t]{2}{*}{ GDP growth } & -0.0016 & -0.0219 & 0.0091 & 0.0072 & -0.0047 & -0.0106 & -0.0086 & -0.0037 & -0.0036 \\
\hline & $(0.016)$ & $(0.017)$ & $(0.017)$ & $(0.016)$ & $(0.014)$ & $(0.013)$ & $(0.013)$ & $(0.015)$ & $(0.014)$ \\
\hline \multirow[t]{2}{*}{ Inflation } & 0.0016 & -0.0118 & 0.0029 & 0.0065 & 0.0021 & 0.0023 & 0.0023 & 0.0114 & $0.0205^{* *}$ \\
\hline & $(0.008)$ & $(0.008)$ & $(0.008)$ & $(0.008)$ & $(0.007)$ & $(0.007)$ & $(0.007)$ & $(0.008)$ & $(0.008)$ \\
\hline \multirow[t]{2}{*}{ Civil war } & 0.1774 & 0.1330 & -0.0004 & 0.1491 & 0.0387 & 0.1095 & 0.1163 & -0.0217 & 0.0184 \\
\hline & $(0.108)$ & $(0.089)$ & $(0.106)$ & $(0.105)$ & $(0.088)$ & $(0.090)$ & $(0.094)$ & $(0.096)$ & $(0.094)$ \\
\hline \multirow[t]{2}{*}{ Poverty } & 0.0827 & $0.1609 * * *$ & -0.0536 & 0.0205 & -0.0124 & -0.0150 & -0.0014 & 0.0167 & $-0.1403^{* *}$ \\
\hline & $(0.065)$ & $(0.062)$ & $(0.075)$ & $(0.052)$ & $(0.051)$ & $(0.045)$ & $(0.047)$ & $(0.062)$ & $(0.062)$ \\
\hline \multirow[t]{2}{*}{ Rule of law } & $-0.2527 * * *$ & $-0.1694 * *$ & $-0.3324 * * *$ & $-0.2844 * * *$ & $-0.2861 * * *$ & $-0.2216^{* * *}$ & $-0.2290 * * *$ & $-0.1701^{*}$ & -0.1041 \\
\hline & $(0.085)$ & $(0.084)$ & $(0.082)$ & $(0.081)$ & $(0.081)$ & $(0.080)$ & $(0.082)$ & $(0.097)$ & $(0.094)$ \\
\hline Observations & 19,783 & 19,783 & 19,783 & 19,783 & 21,355 & 21,355 & 21,355 & 20,610 & 20,610 \\
\hline Number of regions & 260 & 260 & 260 & 260 & 291 & 291 & 291 & 267 & 267 \\
\hline Number of countries & 24 & 24 & 24 & 24 & 24 & 24 & 24 & 24 & 24 \\
\hline Control variables & Yes & Yes & Yes & Yes & Yes & Yes & Yes & Yes & Yes \\
\hline Region fixed effects & Yes & Yes & Yes & Yes & Yes & Yes & Yes & Yes & Yes \\
\hline Ethnicity fixed effects & Yes & Yes & Yes & Yes & Yes & Yes & Yes & Yes & Yes \\
\hline Religion fixed effects & Yes & Yes & Yes & Yes & Yes & Yes & Yes & Yes & Yes \\
\hline
\end{tabular}

